\title{
Petrological and geochemical studies of ultramafic-mafic rocks from the North Puruliya Shear Zone (eastern India)
}

\author{
Aditi Mandal* and Arijit Ray \\ Department of Geology, Presidency University, 86/1 College Street, Kolkata 700 073, India. \\ ${ }^{*}$ Corresponding author.e-mail: aditi_geol05@yahoo.com
}

Ultramafic and mafic rocks occur within a linear belt, trending nearly E-W along North Puruliya Shear Zone of the Chhotanagpur Gneissic Complex (CGC). These rocks are classified as gabbro, norite, gabbronorite, dolerite, diorite, olivine-websterite and lherzolite. Mafic rocks (Group 1) often occur in association with ultramafic variants (Group 2) and sometimes in isolation. A genetic link has been established between these mafic and ultramafic rocks using disposition of ultramafic and mafic rocks in the outcrop, systematic variation in modal mineralogy, co-linearity of plots in biaxial chemical variation diagram. Chemical composition of biotite and clinopyroxene reveal calc-alkaline nature and arc signature in these mafic-ultramafic rocks and whole rock geochemical characters indicate similarity with arc magma in subduction zone setting. The high values of $\mathrm{Mg}$ no. (47-81) and $\mathrm{Al}_{2} \mathrm{O}_{3}$ (5.5-17.9) of mafic rocks indicate primitive, aluminous nature of the parental melt and presence of amphibole and biotite indicate its hydrous nature. The parent mafic melt evolved through fractionation of olivine, spinel, clinopyroxene and plagioclase. The crystal cumulates gave rise to the ultramafic rocks and the associated mafic rocks formed from residual melt. Crustal contamination played an important role in magmatic evolution as evident from variation in abundance of $\mathrm{Rb}$ in different lithomembers. Mafic-ultramafic rocks of the present study have been compared with intra-cratonic layered complexes, mafic-ultramafic rocks of high grade terrain, Alaskan type ultramafic-mafic complex and ophiolites. It is observed that the ultramafic-mafic rocks of present study have similarity with Alaskan type complex.

\section{Introduction}

Mafic-ultramafic rock association is common in different geological environments all over the world. They occur either as members of layered igneous complex like Muscox (Irvine 1980), Skaergaard (McBirney 1995), stillwater (Boudreau 1999); or as components of ophiolite complex (Beard 1986; Biggazzi et al. 1989; Beccaluva et al. 2004; Bonev and Stampfli 2005, 2008) or members of Alaskan type mafic-ultramafic suite (Himmelberg and Loney 1995; Bektas et al. 2007; Tseng et al. 2009) or mafic-ultramafic rocks of high-grade terrain (Leelanandam 1994; Dharmarao et al. 2004) and as members of greenstone belt (Rama Rao et al. 1990). Some of the mafic and ultramafic intrusive rocks occurring along North Puruliya Shear Zone has been studied by earlier workers (Ghosh 1983, 1992; Mahadevan 1992; Kumar and Ahmad 2007; Mandal et al. 2007; Mandal and Ray 2009; Srivastava et al. 2012). All the earlier workers except Mandal et al. (2007) and Mandal and Ray (2009), referred to these mafic-ultramafic rocks as 'metabasic rocks'. Their works were concentrated on magmatic rocks occurring to the western part of Chhotanagpur Gneissic Complex (CGC) falling in the states of Jharkhand and Bihar. Only Mahadevan (1992) worked in the eastern

Keywords. Gabbro-notite; websterite; cumulate; fractional crystallization. 


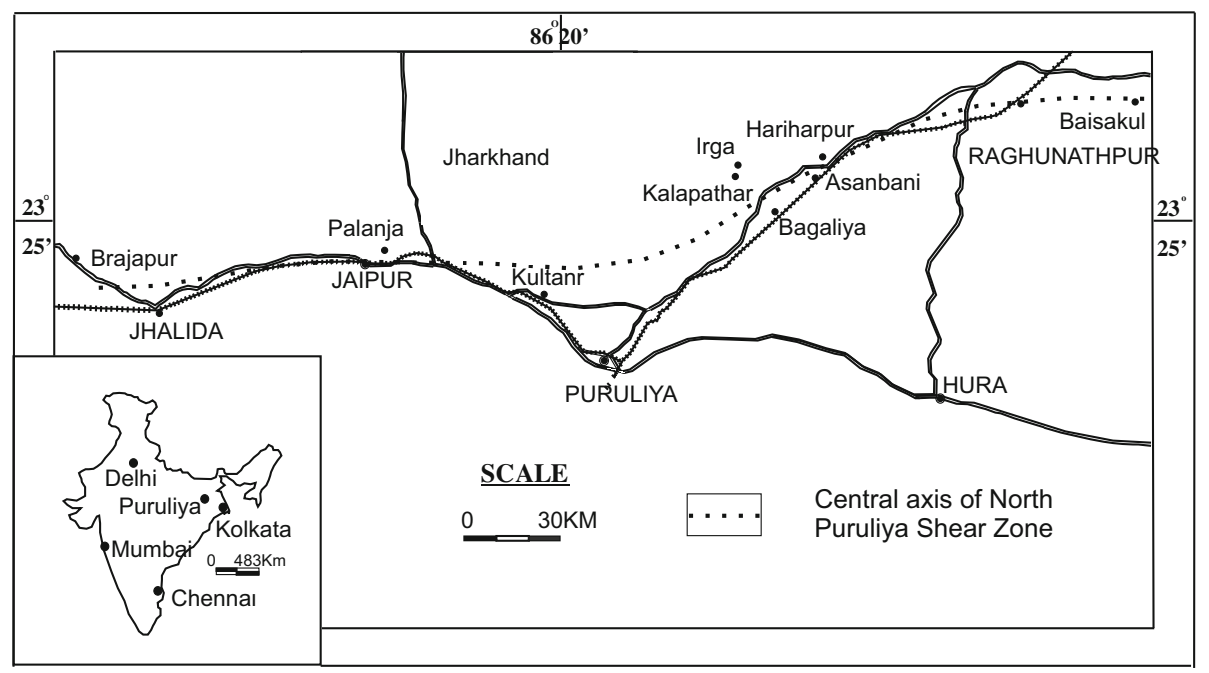

Figure 1. Location map showing the study area along North Puruliya Shear Zone. Central axis of shear zone is marked with dotted line. In the inset, location of Puruliya is shown in the map of India.

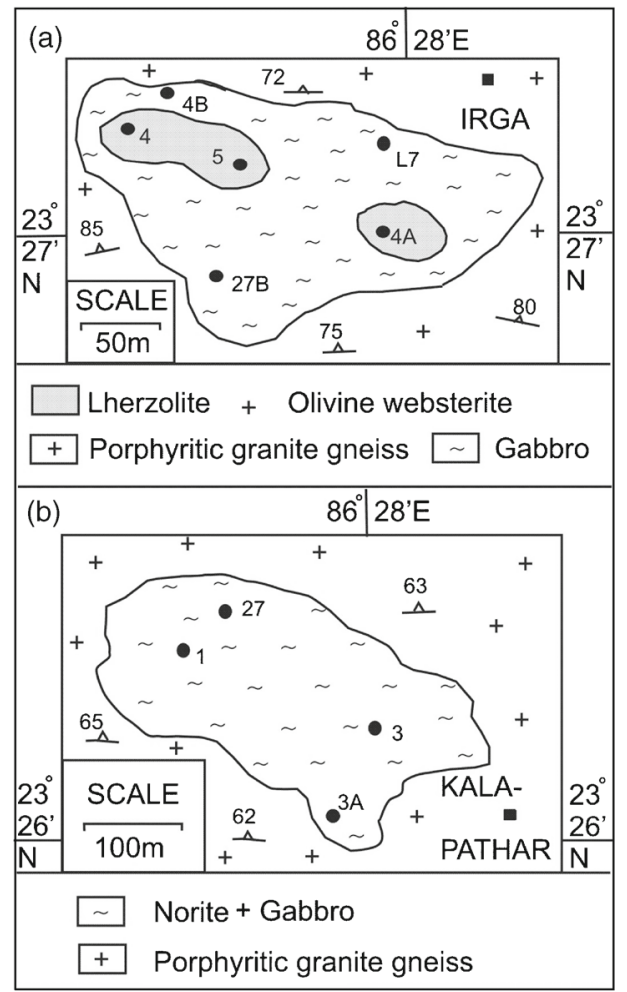

Figure 2. Geological map of the mafic-ultramafic rocks intruding the granite gneiss country rock at Irga (a) and geological map of mafic rocks intruding granite gneiss country rock at Kalapathar (b).

part of CGC covering regions of present study but he has not approached magmatic rocks close to North Puruliya Shear Zone. In this paper, field, petrographic, mineralogical and geochemical data of some new occurrences of ultramafic-mafic rocks (e.g., Brajapur, Palanja, Kultanr, Baisakul) are studied (figure 1), as well as some new data on already reported mafic-ultramafic rocks along
North Puruliya Shear Zone (Mandal et al. 2007; Mandal and Ray 2009) have been presented.

Ultramafic-mafic rocks occurring along North Puruliya Shear Zone are divided into two broad groups on the basis of colour index. Group 1 with lower colour index $(<90)$ represents mafic rocks (vide figures 2a, b, 3, 4a, b) and Group 2 with higher colour index $(>90)$ represents ultramafic rocks (vide figures $2 \mathrm{a}, 3,4 \mathrm{a}, \mathrm{b})$. Important occurrences of mafic rocks from other areas (not along North Puruliya Shear Zone) in CGC are Saltora anorthosite-gabbro suite (Maji et al. 2010); dolerite and norite from NW of Jhalida (Sengupta 1958; Singh 1959) and gabbroic rocks from Belamu-Jaipur area (Baidya and Chakravarty 1988). All these mafic-ultramafic rocks are deformed and metamorphosed. It is evident that mafic and ultramafic rocks of present study are massive without any tectonic foliation and are unmetamorphosed. They may represent youngest event of mafic magmatism in CGC. In the present research work, field, mineralogical, petrological and geochemical studies of the mafic and ultramafic rocks occurring along North Puruliya Shear Zone have been undertaken to understand their genesis and possible paleotectonic setting.

\section{Geological setting}

The area of present study falls within Chhotanagpur Gneissic Complex (CGC). CGC represents a vast granite gneissic terrain covering roughly an area of $60,000 \mathrm{~km}^{2}$, extending through states of West Bengal, Jharkhand, Bihar and Madhya Pradesh. The shield is made up of complex assemblage of Precambrian and Paleozoic rocks which occurs to the north of North Singhbhum Mobile Belt. The terrain preserves records of several episodes of crust forming processes like 


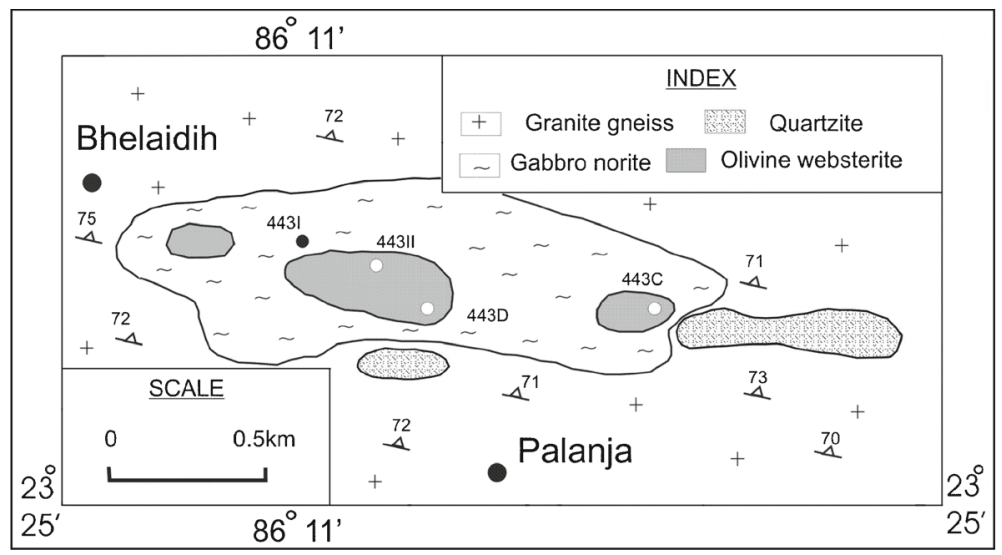

Figure 3. Geological map of the mafic-ultramafic rocks intruding the granite gneiss country rock at Palanja.

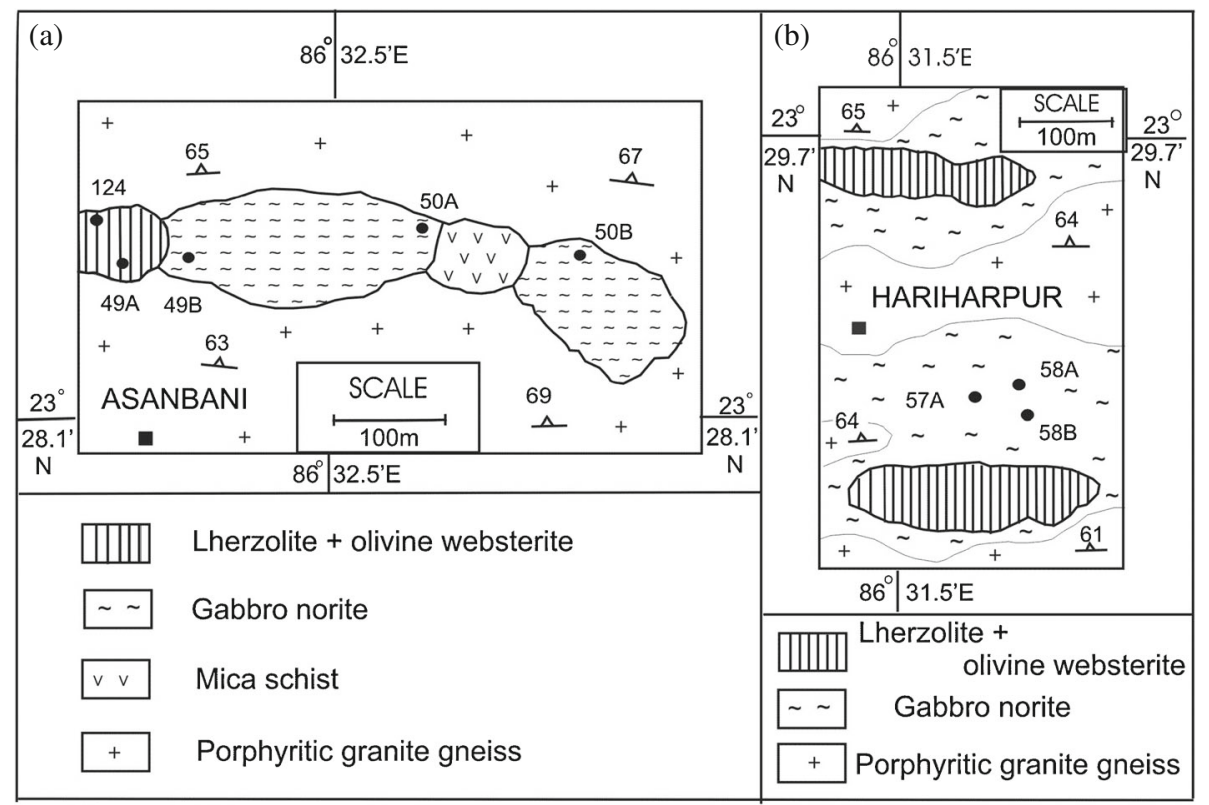

Figure 4. Geological map of the mafic-ultramafic rocks intruding the granite gneiss country rock at (a) Asanbani and (b) Hariharpur.

magmatism, tectonism, sedimentation, metamorphism, migmatisation and mineralization. Large part of CGC is now represented by a gneissgranulite-granite association. The gneisses have both metasedimentary, metaigneous enclaves and granite intrusions of different ages. Besides granitic activity, the CGC has witnessed intrusive magmatic activity preserved as mafic-ultramafic rocks, syenites, nepheline syenites, anorthosites of different ages (table 1). CGC is characterized by the occurrences of two shear zones, namely North Puruliya Shear Zone and South Puruliya Shear Zone. Nearly E-W trending South Puruliya Shear Zone passes through the southern part of CGC affecting low grade metamorphic rocks like phylite. North Puruliya Shear Zone is also E-W trending with a few bends passing through the central part of CGC affecting high grade rocks of amphibolite to granulite facies (Mahadevan 1992). There is a conspicuous increase in grade of metamorphism from south to north of CGC (Mahadevan 1992). The occurrences of high grade litho-assemblage with charnockite, granulite, khondalite and leptinite in association with tonalite gneiss, may signify their close affinity with the Eastern Ghats mobile belt. These typical high grade rocks occur in Santhal Pargana and Purulia districts at the eastern margin of the complex. The relationship between high grade granulite pockets within the largely amphibolites facies rocks may represent deeper level of extensive orogenic domains, which might have served as a basement for the older metasedimentary group of rocks.

The study area forms an integral part of CGC. The country rocks of the study area are granitoid gneiss, both porphyritic and non-porphyritic. The granite gneiss country of the present area contains scattered lenses and patches of mica 
Table 1. Generalized stratigraphic succession of rocks along with radiometric ages of Chhotanagpur Gneissic Complex compiled from works of Sengupta and Sarkar (1968), Das (1977) and Ghosh (1983).

\begin{tabular}{ll}
\hline Eon/Era & \multicolumn{1}{c}{ Rock types } \\
\hline & Alluvium $($ Ma) \\
& Unconformity \\
Mesozoic-Palaeozoic & Ultramafic rock: lherzolite, websterite \\
& Younger fertile pegmatite (REE-enriched) \\
& Alkali feldspar salite granite/syenite, ferruginous apatite rock, \\
& aegirine-riebeckite granite gneiss, carbonatite \\
& Unconformity \\
& Meta-mafics: meta-dolerite, meta-gabbro, meta-norite \\
& Older pegmatites (including rare metal type), aplites and quartz veins \\
& Massive leucogranitoid rocks \\
& Porphyritic granitoid gneisses, \\
& Nonporphyritic granitoid gneisses, migmatites \\
& Amphibolites, mica schists and allied rocks, khondalites, \\
& quartzites, calc-silicate gneisses, marbles, mafic granulites \\
\hline
\end{tabular}

schist, calc-silicate rock, quartzite, amphibolite, basic granulite, charnockite, khondalite, migmatite, meta-gabbro, salite granite and syenite and apatite-magnetite-chert rock and ultramafic intrusive. The regional trend of the metamophites and granitoid gneiss is generally $\mathrm{E}-\mathrm{W}$ to ENE-WSW and the dip is generally northerly. A review of the scanty age data from Purulia district and the adjoining Jharkhand suggest that the age of the metamorphites ranges from 1000-1400 Ma and the age of the porphyritic and non-porphyritic granitoid gneisses from 800-900 Ma. The salite granite and syenite (Das and Bhattacharyya 2007) was dated to be 475 Ma (Ghosh 1983) of age, apatite-magnetite-chert rock and the ultramafic intrusive are younger but their age is not known, although an ultramafic intrusion of hornblendite (later named as peridotite) from nearby Palamau, Bihar is dated to be of $275 \mathrm{Ma}$ age (Ghosh 1983). The study area belongs to the northern part of CGC. Mafic and ultramafic rocks occur along North Puruliya Shear Zone mentioned above which passes through the high grade (granulite facies) metamorphic rocks of CGC (Ghosh 1983; Mahadevan 1992; Mandal et al. 2007; Mandal and Ray 2009). Country rocks suffered three phases of folding $\left(\mathrm{F}_{1}\right.$, $\mathrm{F}_{2}, \mathrm{~F}_{3}$ ) and a final phase of east-west shearing (Baidya 1987). The shearing produced S-C fabric, ultra-mylonite in the high grade metamorphic country rocks. Three episodes of metamorphism have been recorded in the rocks of CGC (Baidya et al. 1989; Chatterjee et al. 2008; Maji et al. 2008). Ray Barman and Bisui (1994) determined $\mathrm{Rb}$-Sr age for the porphyritic hypersthene granite of Bero, near Raghunathpur, NE Puruliya $(1071+64 \mathrm{Ma})$ and migmatites from Murguma, Ayodhya Pahar, SW Puruliya (1178+61 Ma). The Saltora anorthosite-gabbro yield $\mathrm{U}-\mathrm{Pb}$ age of $1.55 \mathrm{Ga}$ (Chatterjee et al. 2008). According to
Misra (2006), rocks of CGC were evolved between 2.3 and $1.0 \mathrm{Ga}$ and major magmato-metamorphic events took place around 2.5-2.3, 1.6, 1.0 and 0.9 $\mathrm{Ga}$ based on U-Pb method. The mafic and ultramafic rocks of present study are nearly undeformed (marginally sheared) and unmetamorphosed and thus appear to be younger than other mafic rocks of CGC which are deformed and metamorphosed.

\section{Field occurrence, petrography and mineralogy}

The intrusive rocks of the study area are divided into Group 1 or mafic group of rocks and Group 2 or ultramafic group of rocks based on relative modal abundances of mafic and felsic minerals (table 2). Both the groups are exposed as ellipsoidal, elongate bodies having sharp contact with the gneissic country rocks. Effect of contact metamorphism of the country rocks adjacent to the intrusive are not found. Group 2 ultramafic rocks occur as small pockets or bands associated with mafic rocks. But Group 1 mafic rocks sometimes occur in isolation.

Group 1 rocks, on the basis of modal proportion of plagioclase, orthopyroxene and clinopyroxene, are divided into three categories namely gabbro, norite and gabbro-norite. Group 2 rocks are similarly classified into two categories, namely lherzolite and olivine websterite on the basis of relative proportion of olivine, orthopyroxene and clinopyroxene.

Gabbros occur as boulders in the form of a small mound near Brajapur, as scattered boulders associated with ultramafic in Irga, and as huge boulders associated with norite near Kalapathar. The rock is coarse-grained, greyish-white with patches of dark mafic minerals. Major minerals of the rock are clinopyroxene, plagioclase, 
Table 2. Modal (volume\%) composition of mafic and ultramafic rocks along North Puruliya Shear Zone.

\begin{tabular}{|c|c|c|c|c|c|c|c|c|c|c|}
\hline $\begin{array}{l}\text { Sample } \\
\text { no. }\end{array}$ & Group & $\mathrm{Ol}$ & Opx & Cpx & Plag & K-feld & Qtz & $\mathrm{Hbl}$ & $\mathrm{Bt}$ & Opq \\
\hline $\mathrm{L} 7$ & 1 & 0 & 17 & 11 & 30 & 2.8 & 0 & 35.8 & 1.2 & 2.2 \\
\hline $57 \mathrm{~A}$ & & 0 & 29 & 0 & 40 & 1.2 & 0 & 2.1 & 24 & 3.7 \\
\hline $58 \mathrm{~B}$ & & 0 & 5.2 & 30 & 28 & 2 & 0 & 14 & 16.7 & 4.1 \\
\hline $27 \mathrm{~B}$ & & 0 & 3.3 & 12 & 39 & 0 & 0 & 32 & 12.9 & 0.8 \\
\hline 8 & & 1.2 & 0 & 3.1 & 58.1 & 0 & 0 & 25.3 & 4.3 & 8 \\
\hline $58 \mathrm{~A}$ & & 2 & 20 & 0 & 30 & 0 & 19 & 15 & 10 & 4 \\
\hline $4 \mathrm{~B}$ & & 0 & 30.9 & 42.8 & 10.8 & 2.9 & 0 & 8.1 & 3.8 & 0.7 \\
\hline 119 & & 0.5 & 21 & 11 & 51 & 0 & 0 & 15 & 0 & 1.5 \\
\hline 120 & & 0 & 24 & 18 & 32 & 0.9 & 2.4 & 0 & 15.4 & 7.3 \\
\hline $70 \mathrm{D}$ & & 0 & 27 & 15 & 32 & 1.1 & 2.9 & 2.6 & 13 & 6.4 \\
\hline 122 & & 0.7 & 0 & 51 & 37.2 & 0 & 0 & 7.1 & 0 & 4 \\
\hline 1 & & 0 & 13.6 & 50.4 & 16 & 0 & 0 & 11.8 & 7.8 & 0.4 \\
\hline 3 & & 1.5 & 3.3 & 10.4 & 38.2 & 1 & 0 & 32.2 & 12.6 & 0.8 \\
\hline 7 & 2 & 16.5 & 14.3 & 31.9 & 8.2 & 0 & 0 & 0 & 28.7 & 0.4 \\
\hline 124 & & 8.2 & 42 & 44.2 & 2.2 & 0 & 0 & 2.8 & 0.1 & 0.5 \\
\hline $443 \mathrm{II}$ & & 44.6 & 12 & 16.9 & 5 & 0 & 0 & 6.2 & 14.6 & 0.7 \\
\hline 121 & & 11 & 3.5 & 65 & 15.8 & 0 & 0 & 2.1 & 2.3 & 0.3 \\
\hline $443 \mathrm{~A}$ & & 10.7 & 3.5 & 64.8 & 16.3 & 0 & 0 & 2.1 & 2.3 & 0.3 \\
\hline 4 & & 7.9 & 23.1 & 50 & 6.9 & 0 & 0 & 0 & 10.9 & 1.2 \\
\hline 5 & & 9.2 & 7.9 & 55.3 & 10.3 & 1 & 0 & 6 & 8.7 & 1.6 \\
\hline $4 \mathrm{~A}$ & & 30 & 25 & 16 & 14 & 0 & 0 & 0 & 12 & 3 \\
\hline
\end{tabular}

Ol: olivine, Opx: orthopyroxene, Cpx: clinopyroxene, Plag: plagioclase, K-feld ${ }^{+}$: K-feldspar, Qtz: quartz, Hbl: hornblende, Bt: biotite, Opq: opaque.

L7: Gabbro norite, about $100 \mathrm{~m}$ WSW of Irga. 57A: Diorite, about $50 \mathrm{~m}$ SE of Hariharpur.

58B: Diorite, about $30 \mathrm{~m}$ ESE of 57A. 27B: Gabbro, about $125 \mathrm{~m}$ SW of Irga.

8: Gabbro norite, about $200 \mathrm{~m} \mathrm{NE}$ of Asanbani 58A: Gabbro norite, about $20 \mathrm{~m}$ NNW of 58B.

4B: Gabbro, about $125 \mathrm{~m} \mathrm{~W}$ of Irga. 7: Lherzolite + olivine websterite, about $100 \mathrm{~m}$ SE of Hariharpur.

124: Websterite, about $200 \mathrm{~m}$ NNW of Asanbani. 121: Olivine websterite, about $600 \mathrm{~m}$ NE of Palanja.

443A: Olivine websterite, about $400 \mathrm{~m} \mathrm{SE}$ of Bhelaidih, 443II: Olivine websterite, about $600 \mathrm{~m} \mathrm{E} \mathrm{of} 443 \mathrm{~A}$.

4: Olivine websterite, about $200 \mathrm{~m}$ WSW of Irga. 5: Olivine websterite, about $100 \mathrm{~m}$ ESE of sample 4.

119: Dolerite, Baisakul. 120: Norite, Kultanr. 70D: Norite, Kultanr. 122: Gabbro, Brajapur.

1: Norite, $350 \mathrm{~m} \mathrm{NW}$ of Kalapathar. 3: Gabbro norite, about $300 \mathrm{~m}$ ESE of sample 1.

4A: Lherzolite, about $100 \mathrm{~m} \mathrm{SW}$ of Irga.

hornblende with minor amount of olivine, orthopyroxene, biotite, apatite and opaque. Plagioclase $\left(10-40 \%, \mathrm{An}_{45}\right)$ shows bimodal grain size distribution pattern. Smaller grains of plagioclase form mosaic around larger grains of plagioclase as well as large pyroxene grains. Clinopyroxenes (12-43\%) occur as large subhedral grains frequently replaced by hornblende along margin and are greater in abundance than orthopyroxenes. Clinopyroxene grains are identified as diopside and augite. Orthopyroxene (3-31\%) is hypersthene and occur as large subhedral grains enveloped by hornblende corona along margins. Both the pyroxenes contain numerous inclusions of plagioclase, biotite, hornblende, patchy opaque and tiny opaque inclusions in the form of schiller plates. Hornblendes (8-33\%) are of two types: (a) greenish brown, pleochroic variety encircling orthopyroxene sometimes with olivine at the core (figure 5) and (b) green tremilote-actinolite with spongy or fibrous habit occuring as replacement product of pyroxene.
Different generations of biotite (3-13\%) show high angle between each other. Olivine occurs rarely as rounded, fractured grain, partly altered to serpentine and skeletal magnetite with reaction structure. Apatites are included within biotite in a linear fashion. Allanite is associated with the opaques $(\simeq 1 \%)$. Ilmenite occurs as very fine to coarse grain associated with hornblende and pyroxenes. Magnetite occurs as irregular grains intimately associated with serpentinised olivine.

Norite occurs as large boulders of brownish grey colour with darker lines of mineral lineation looking like ropy structure (figure 6). This coarse-grained rock occurs as isolated exposure in Kultanr, in association with gabbro in Kalapathar and associated with ultramafic olivine websterite in Palanja. The major constituent minerals are orthopyroxene, clinopyroxene, plagioclase, hornblende and biotite with minor amount of opaque minerals and rare K-feldspar. Plagioclase $\left(16-32 \%, \mathrm{An}_{54}\right)$ occurs mostly as coarse, subhedral, tabular grains. 


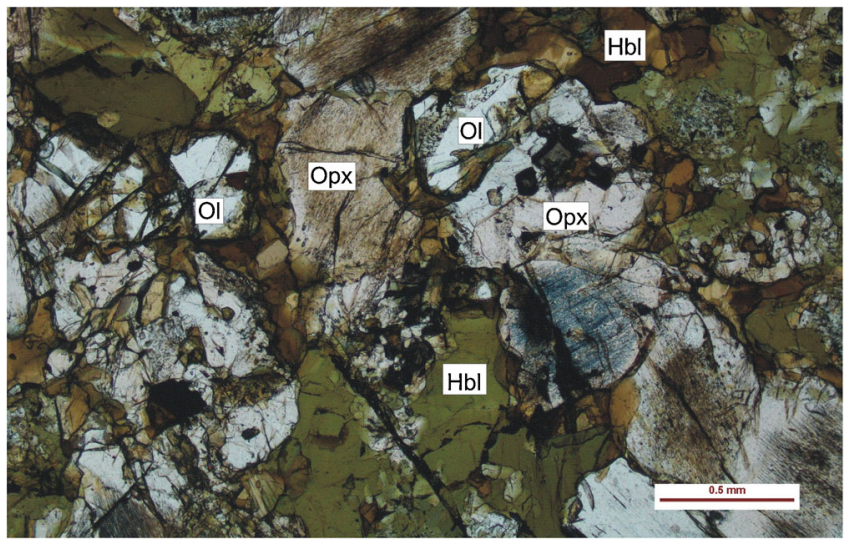

Figure 5. Reaction rim of hornblende (dark brown) around orthopyroxene (light brown with dusty inclusions) and olivine (white with prominent cracks) in gabbronorite of Irga. Hbl: Hornblende, Opx: orthopyroxene, Ol: olivine.

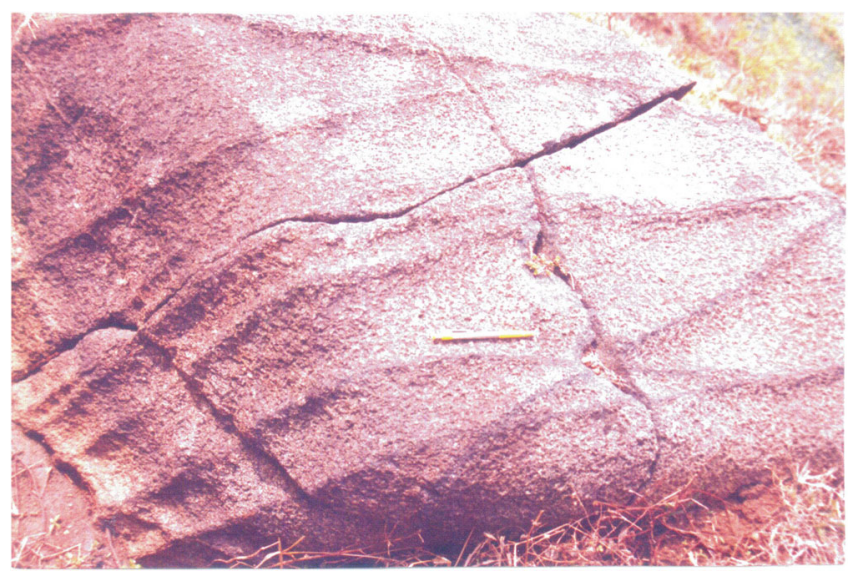

Figure 6. Rope-like structure on boulders of metanorite at Kultanr. The structure is possibly formed by pyroxene rich layers.

Few megacrysts of plagioclase show thin zone of granulation across twin lamellae. Myrmekitic texture is shown by some grains of plagioclase. Hypersthane (13-27\%) occurs as subhedral tabular grains. It forms aggregate with clinopyroxene, biotite and opaque. Megacrysts of hypersthane occasionally contain equant, medium-sized inclusions of clinopyroxene. Clinopyroxene (15-51\%) is subhedral, equant, medium-sized grains (diopside/salite in composition) occasionally enclosed within hyparsthane. Both the pyroxenes have some common features: (i) biotitisation along prismatic cleavage traces; (ii) frequent presence of tiny opaques forming schillers; (iii) formation of clusters of yellow-brown biotite along the contact of pyroxene-plagioclase. Orthopyroxenes show greater abundance than clinopyroxenes. Hornblendes $(2-12 \%)$ occur as medium-sized elongate prisms generally associated with pyroxenes. Yellow-brown, pleochroic biotites (7-13\%) occur as clusters of laths along the marginal part of pyroxene in contact with plagioclase. Biotites show inclusions of medium-sized, elliptical grains of apatite. Hornblende is pleochroic in shades of lightgreen, subhedral, small-sized grain intimately associated with pyroxenes along their contact with plagioclase. Tremolite, a fibrous variety of amphibole occurs also as thin laths along the cleavage of pyroxenes. Opaques (1-7\%) occur as schillers and medium-sized irregular grains associated with pyroxene, biotite, hornblende. Smaller plagioclase grains are frequently enclosed by large pyroxene plates defining sub-ophitic texture. Norites show more or less the same texture as that of gabbro. Only the norites of Palanja show granulitic mosaic with less abundance of hornblende and biotite than the other occurrences.

Gabbro-norite occurs as boulders associated with ultramafic rocks in Irga, Hariharpur and Asanbani and in isolation at Kalapathar. This coarsegrained, dark-grey coloured rock shows similar petrography as those of gabbro and norite, only the proportion of two pyroxenes varies and olivine is rare. Gabbro-norite of Kalapathar shows the presence of olivine (1-2\%) which is slightly more forsteritic $\left(\mathrm{Fo}_{74.3-74.6}\right)$ than that of Asanbani $\left(\mathrm{Fo}_{73.2}\right)$. Orthopyroxene $(0-20 \%)$ is richer in $\mathrm{Mg}$ in Asanbani $\left(\operatorname{En}_{77.7-79.9}\right)$ than in Kalapathar $\left(\operatorname{En}_{71.8-72.7}\right)$, clinopyroxene $(0-10.4 \%)$ is diopside/salite $\left(\mathrm{Wo}_{49} \mathrm{En}_{43} \mathrm{Fs}_{8}\right.$ to $\left.\mathrm{Wo}_{48} \mathrm{En}_{44} \mathrm{Fs}_{8}\right)$ and plagioclase $(30-58.1 \%)$ is andesine to labradorite $\left(\mathrm{An}_{43.5}-\mathrm{An}_{54.9}\right)$. Hornblendes $(15-32.2 \%)$ are relatively greater in proportion in gabbro-norite of Irga than in Asanbani whereas opaques (0.8$8 \%$ ) show greater abundance. Isolated exposure of gabbro-norite of Irga shows greater effect of recrystallisation, whereas Hariharpur and Asanbani gabbro-norites are relatively fresh with characteristic ophitic/subophitic texture.

Diorite occurs as a small white band $(1.5 \mathrm{~m}$ thick) with dark streaks (unmappable in dimension) within gabbro-norite in Hariharpur. This coarse-grained rock is composed mainly of orthopyroxene, clinopyroxene, plagioclase and biotite with a minor amount of K-feldspar, hornblende and opaque. Orthopyroxene ( $5 \%$, hypersthene) occurs as medium- to large-stout, equidimensional and elongated grains, always associated with clinopyroxene or amphibole. Some of the orthopyroxenes occur as replacement product of olivine as indicated by their characteristic fracture and rounded shape. Clinopyroxene (30\%, augite) grains are somewhat rounded than orthopyroxene and generally smaller in size. Both ortho and clinopyroxenes show inclusions of fine needle-like or patchy irregular opaques within them. Feldspars are mostly plagioclase $(28 \%)$ with little proportion of Kfeldspar (2\%). Amphiboles (14\%, tremolite) are abundant and occur as short and medium-sized 
prisms. Smaller flakes of biotite $(17 \%)$ occurrence always associated with amphibole and pyroxenes.

Dolerite occurs as a small bouldery outcrop in Baisakul. The rock is medium-grained, darkcoloured and is composed dominantly of plagioclase, hornblende, orthopyroxene, clinopyroxene and biotite with minor amount of opaque and rare olivine.

Plagioclase $\left(\mathrm{An}_{63}-\mathrm{An}_{89}\right)$ shows bimodal grainsize distribution pattern. Medium-sized laths form nearly polygonal spaces filled up by smaller anhedral pyroxenes and opaques giving rise to intergranular type of texture and others occur as smaller-grained recrystallized aggragate. Pyroxenes are hypersthenes and diopside. Orthopyroxenes generally occur as subhedral, elongate and clinopyroxenes as subhedral, equant grains. They also occur as thin reaction rims around olivine. Hypersthene show numerous tiny pinkish-brown inclusions along cleavage planes giving rise to turbid appearance and these irregular mediumsized opaque inclusions are oriented haphazardly. Olivine occurs as medium-sized rounded grains surrounded by hypersthane and brownish hornblende. The olivine grain, at the core of the above corona is, at many places, represented only by its characteristic fracture and rounded nature. Hornblende $\left(\mathrm{Z}^{\prime} \wedge \mathrm{C}=20^{\circ}\right)$ is small- to medium-grained, anhedral to subhedral and show greater abundance than other mafic minerals. There are two types of hornblende, green and brown. Green hornblende is magnesio-hornblende ( $\mathrm{MgO}: 13.59-14.48)$ and brown hornblende is ferro-hornblende (FeO: 32.7933.95) in composition. Biotites are of different sizes from tiny flakes to robust laths. They are always associated with hornblende, apatite and opaques. Apatites are elliptical grains within large grains of hornblende and biotite. Rutile occurs as patches within hornblende and plagioclase. Opaques are

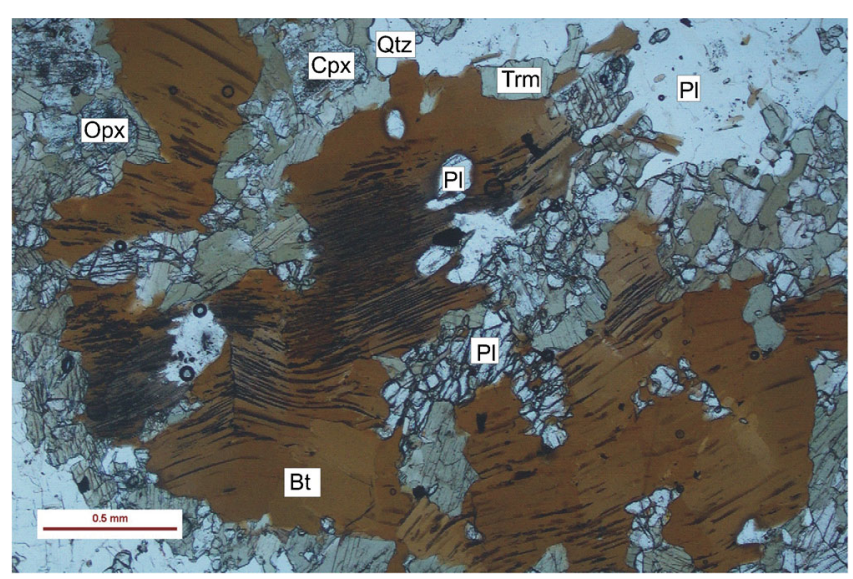

Figure 7. Kinking in biotite (brownish yellow) in diorite at Hariharpur. Bt: Biotite, Pl: plagioclase, Qtz: quartz, Trm: tremolite, Opx: orthopyroxene, Cpx: clinopyroxene. mainly ilmenite $\left(\mathrm{FeO}-50.18, \mathrm{TiO}_{2}-46.55\right)$ with occasional magnetite occurring associated with hornblende, biotite and apatite. Plagioclase phenocrysts are set in a groundmass made up of flakes of biotite and hornblende and gives rise to porphyritic texture.

Evidence of deformation in mafic rocks are shown by bending and off-set of twin lamellae and core-rim structure in plagioclase, bending of cleavage planes in orthopyroxene, kinking (figure 7) of biotite and sheared or granulated appearance of the quartzofeldspathic minerals.

Lherzolite occur as boulders associated with olivine websterite at Irga and Hariharpur. It is not possible to demarcate the lherzolitic part in the field as it is based only on the proportion of olivines present in the rock. This is a coarsegrained, dark greenish-black coloured rock with bronze patches and is composed dominantly of olivine, orthopyroxene, clinopyroxene, plagioclase and phlogopite with minor amount of opaque minerals. Olivine occurs as: (i) coarse, rounded, subhedral grains in the interspaces of pyroxene, plagioclase and phlogopite, (ii) subhedral grains partially or completely enclosed in orthopyroxene and clinopyroxene and (iii) rarely form smaller grained aggregates. Olivines at places are converted to orthopyroxene or clinopyroxene. Pyroxenes show simple twinning. Olivines show double range of composition at Irga, one is $\mathrm{Fo}_{61.2}-\mathrm{Fo}_{62.7}$ and another is $\mathrm{Fo}_{71.9}-\mathrm{FO}_{72.1}$, whereas olivine is more forsteritic at Hariharpur $\left(\mathrm{Fo}_{75.4}-\mathrm{Fo}_{75.8}\right)$. Diopside occurs as coarse, subhedral, stumpy plates which contain irregular patches of phlogopite, tiny opaques, green-brown hornblende and subrounded grains of olivine. Orthopyroxene is bronzite and occur as coarse tabular plates like diopside. It

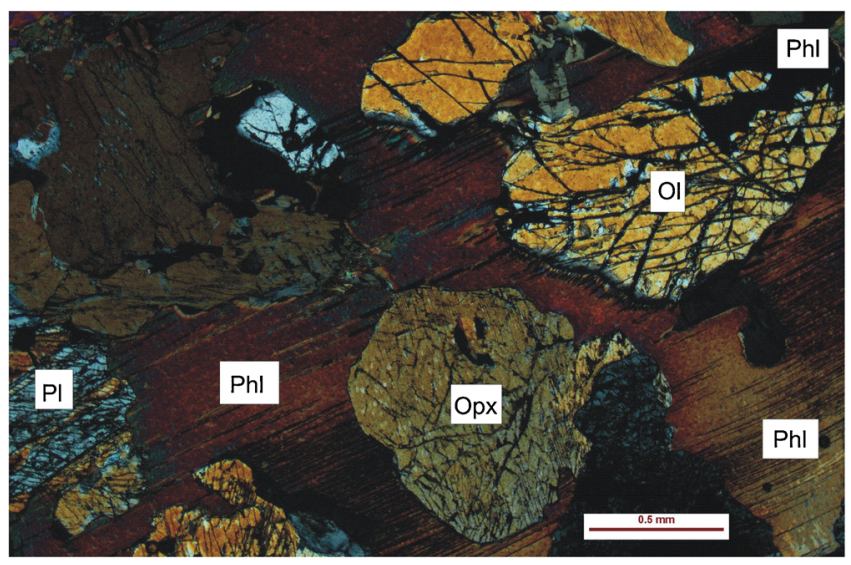

Figure 8. Large lath of poikilitic phlogopite (dark reddish brown) enclosing olivine (white/yellow with cracks), orthopyroxene (yellow with rectangular cleavage traces) and plagioclase (with lamellar twinning) in olivine websterite at Palanja. Phl: Phlogopite, Ol: olivine. Opx: orthopyroxene, Cpx: clinopyroxene. 


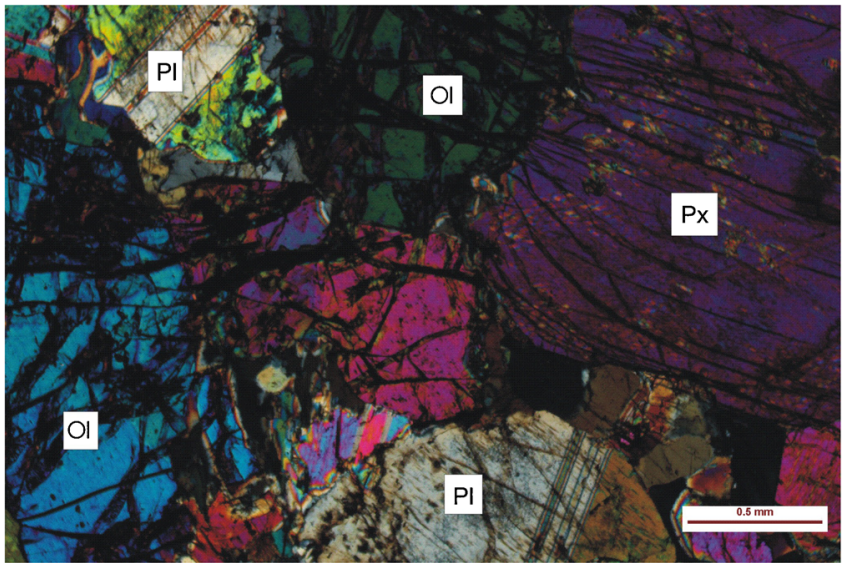

Figure 9. Cumulus texture defined by olivine, pyroxene and plagioclase in olivine websterite of Palanja. Ol: Olivine, Px: pyroxene, Pl: plagioclase.

is richer in $\mathrm{Mg}$ at Hariharpur $\left(\mathrm{En}_{77.1-79.9}\right)$ than at Irga $\left(\operatorname{En}_{75.6-76.6}\right)$. Sometimes orthopyroxenes and clinopyroxenes contain inclusions of schiller plates, tiny biotite and hornblende along cleavage planes. Plagioclase $\left(\mathrm{An}_{60}-\mathrm{An}_{76}\right)$ occurs as coarse subhedral grains interstitial to pyroxenes. Hornblendes are light brownish green, medium-sized prismatic or light-green, spongy and fibrous in nature. They occur as corona around orthopyroxene along the contact with plagioclase large laths of poikilitic phlogopite (Mg no. 83-84), sometimes include olivine, pyroxene and plagioclase grains (figure 8). Opaques mostly occur as alteration product along the cracks of olivine and tiny inclusions within pyroxenes and are ilmenite (FeO: 47.7, $\mathrm{TiO}_{2}$ : 48.9) and magnetite. Cumulus texture defined by accumulation of coarse, subhedral, stumpy plates and equant grains of clinopyroxene, orthopyroxene, olivine and sporadic interstitial plagioclase, phlogopite, amphibole and opaque are characteristics of lherzolite (figure 9). Large poikilitic grains of phlogopite and hornblende are found to enclose smaller grains of clinopyroxene, plagioclase and ilmenite.

Olivine websterite is the most common type of ultramafic rock in the study area. It occurs as boulders associated with lherzolite at Irga and Hariharpur, with norite at Kultanr and with gabbro-norite at Asanbani. This is a coarsegrained, dark-coloured rock. The constituent minerals, texture and structure are similar to that of lherzolite, only the proportion of olivine varies. Olivines are lesser in abundance in websterite than lherzolite. Olivine of Asanbani websterite is slightly more forsteritic $\left(\mathrm{FO}_{73.2}\right)$ than websterite of Irga $\left(\mathrm{FO}_{71.9-72.1}\right)$, whereas orthopyroxene of Asanbani websterite show wider range $\left(\operatorname{En}_{71.2}-\mathrm{En}_{77.1}\right)$ than Irga $\left(\mathrm{En}_{75.6}-\mathrm{En}_{76.6}\right)$. Clinopyroxene of Irga websterite ranges in composition from $\mathrm{Wo}_{45} \mathrm{En}_{46} \mathrm{Fs}_{8}$ to
$\mathrm{Wo}_{47} \mathrm{En}_{45} \mathrm{Fs}_{8}$ and from $\mathrm{Wo}_{49} \mathrm{En}_{45} \mathrm{Fs}_{6}$ to $\mathrm{Wo}_{50} \mathrm{En}_{43}$ $\mathrm{Fs}_{7}$ in websterite of Asanbani. Plagioclase show two ranges of An-content, one is $\mathrm{An}_{45}-\mathrm{An}_{46.1}$ and the other is $\mathrm{An}_{52.1} \mathrm{An}_{73.6}$. Mg-number of biotite is 87 .

Evidence of deformation in mafic and ultramafic rocks are shown by bending of twin lamellae and offset of twin lamalle in plagioclase, kinking of biotite, bending of cleavage planes in orthopyroxene, recrystallized aggregate of olivine and twinning in pyroxene.

All the intrusives of present study show igneous mineral assemblage and truly igneous texture and structure. Minerals are fresh and nearly unmetamorphosed. A fairly detailed petrographic description of some of the mafic and ultramafic rocks of North Puruliya Shear Zone has been stated by Mandal et al. (2007) and Mandal and Ray (2009).

Modal analyses of the intrusives have been carried out for their classification, naming and characterization. Modal values of constituent minerals are given in table 2. Based on IUGS scheme of classification for plutonic rocks (Streckeisen 1973), the magmatic rocks of the study area have been classified as gabbro, norite, gabbro-norite, diorite, dolerite, olivine websterite and lherzolite.

\section{Analytical methods}

Chemical composition of constituent minerals (tables 3, 4, 5) were determined with an automated wave-length dispersive CAMECA SX 100 electron microprobe and associated software at the Central Petrological Laboratory, CHQ, Geological Survey of India, Kolkata. Analyses were performed with a $15 \mathrm{kV}$ accelerating voltage, $12 \mathrm{nA}$ current, 1 micron beam size. All natural mineral standards were used except for Mn and Ti for which synthetic standards were used. The replicate analyses show identical results. The precision of analyses is within the error limit of $\pm 3 \%$.

Major element composition of mafic and ultramafic intrusive (table 6) is determined from Wadia Institute of Himalayan Geology, Dehradun using fused pellets/pressure powder pellets. Nominal analysis time is $300 \mathrm{~s}$ for all major oxides. XRF System Configuration Bruker S8 Tiger Sequential X-ray Spectrometer with END WINDOW Rh Xray tube. The overall accuracy $(\% \mathrm{RSD})$ for major and minor oxides is $<5$. No filter is used for major oxides. Vacuum path is $20 / 40 \mathrm{kV}$. Standard used for calibration is BHVO-1.

Trace element abundances (table 6) of mafic and ultramafic rocks were determined from National Geophysical Research Institute, Hyderabad using HR-ICPMS from homogenized sample powder which was dissolved in reagent grade $\mathrm{HF}: \mathrm{HNO}_{3}$ acid mixture in Savillex ${ }^{\circledR}$ screwtop vessels. Standard used is JB-2 for checking precision and 
Table 3. Representative olivine and plagioclase composition of mafic and ultramafic rocks along North Puruliya Shear Zone.

\begin{tabular}{|c|c|c|c|c|c|c|c|c|c|}
\hline \multicolumn{5}{|c|}{ Olivine } & \multicolumn{5}{|c|}{ Plagioclase } \\
\hline \multirow[b]{2}{*}{ Group } & \multicolumn{2}{|l|}{1} & \multicolumn{2}{|l|}{2} & \multirow[b]{2}{*}{ Group } & \multicolumn{2}{|l|}{1} & \multicolumn{2}{|l|}{2} \\
\hline & $\overline{\mathrm{Av}}(n=7)$ & S.D. & $\overline{\mathrm{Av}(n=23)}$ & S.D. & & $\overline{\mathrm{Av}}(n=15)$ & S.D. & $\overline{\mathrm{Av}}(n=19)$ & S.D. \\
\hline $\mathrm{SiO}_{2}$ & 34.62 & 2.67 & 44.95 & 7.58 & $\mathrm{SiO}_{2}$ & 55.86 & 3.18 & 52.58 & 2.62 \\
\hline $\mathrm{TiO}_{2}$ & 0.00 & 0.00 & 0.02 & 0.02 & $\mathrm{TiO}_{2}$ & 0.00 & 0.01 & 0.02 & 0.05 \\
\hline $\mathrm{Al}_{2} \mathrm{O}_{3}$ & 0.01 & 0.01 & 0.57 & 0.67 & $\mathrm{Al}_{2} \mathrm{O}_{3}$ & 26.94 & 2.28 & 28.84 & 1.76 \\
\hline $\mathrm{FeO}$ & 39.36 & 15.05 & 24.11 & 2.01 & $\mathrm{FeO}$ & 0.11 & 0.09 & 0.17 & 0.37 \\
\hline $\mathrm{MnO}$ & 0.63 & 0.28 & 0.35 & 0.09 & $\mathrm{MnO}$ & 0.01 & 0.02 & 0.01 & 0.02 \\
\hline $\mathrm{MgO}$ & 25.01 & 12.35 & 29.33 & 7.21 & $\mathrm{MgO}$ & 0.01 & 0.01 & 0.20 & 0.79 \\
\hline $\mathrm{CaO}$ & 0.02 & 0.03 & 0.19 & 0.20 & $\mathrm{CaO}$ & 10.11 & 3.09 & 12.48 & 1.92 \\
\hline $\mathrm{Na}_{2} \mathrm{O}$ & 0.02 & 0.02 & 0.01 & 0.01 & $\mathrm{Na}_{2} \mathrm{O}$ & 6.24 & 1.46 & 4.75 & 1.17 \\
\hline $\mathrm{K}_{2} \mathrm{O}$ & 0.01 & 0.01 & 0.00 & 0.01 & $\mathrm{~K}_{2} \mathrm{O}$ & 0.15 & 0.08 & 0.12 & 0.08 \\
\hline $\mathrm{Cr}_{2} \mathrm{O}_{3}$ & 0.02 & 0.03 & 0.03 & 0.04 & $\mathrm{Cr}_{2} \mathrm{O}_{3}$ & 0.01 & 0.01 & 0.02 & 0.02 \\
\hline $\mathrm{NiO}$ & 0.09 & 0.15 & 0.04 & 0.10 & $\mathrm{NiO}$ & 0.01 & 0.03 & 0.01 & 0.03 \\
\hline $\mathrm{Si}$ & 1.00 & 0.00 & 1.00 & 0.00 & $\mathrm{Si}$ & 5.10 & 0.26 & 4.86 & 0.19 \\
\hline $\mathrm{Al}$ & 0.00 & 0.00 & 0.01 & 0.02 & $\mathrm{Al}$ & 2.90 & 0.26 & 3.14 & 0.19 \\
\hline $\mathrm{Ti}$ & 0.00 & 0.00 & 0.00 & 0.00 & $\mathrm{Ti}$ & 0.00 & 0.00 & 0.00 & 0.00 \\
\hline $\mathrm{Fe}_{2}$ & 0.98 & 0.43 & 0.47 & 0.11 & $\mathrm{Fe}_{2}$ & 0.01 & 0.01 & 0.01 & 0.03 \\
\hline Mn & 0.02 & 0.01 & 0.01 & 0.00 & $\mathrm{Mn}$ & 0.00 & 0.00 & 0.00 & 0.00 \\
\hline $\mathrm{Mg}$ & 1.05 & 0.44 & 1.04 & 0.42 & $\mathrm{Mg}$ & 0.00 & 0.00 & 0.03 & 0.12 \\
\hline $\mathrm{Ca}$ & 0.00 & 0.00 & 0.00 & 0.00 & $\mathrm{Ca}$ & 0.99 & 0.31 & 1.24 & 0.21 \\
\hline $\mathrm{Na}$ & 0.00 & 0.00 & 0.00 & 0.00 & $\mathrm{Na}$ & 1.10 & 0.25 & 0.85 & 0.20 \\
\hline $\mathrm{K}$ & 0.00 & 0.00 & 0.00 & 0.00 & $\mathrm{~K}$ & 0.02 & 0.01 & 0.01 & 0.01 \\
\hline $\mathrm{Ni}$ & 0.00 & 0.00 & 0.00 & 0.00 & & & & & \\
\hline \multirow[t]{2}{*}{ Cations } & 3.05 & 0.02 & 2.53 & 0.51 & $\mathrm{Ab}$ & 52.48 & 12.76 & 40.41 & 9.33 \\
\hline & & & & & An & 46.64 & 13.23 & 58.91 & 9.63 \\
\hline Fo & 52.00 & 22.00 & 68.00 & 5.00 & Or & 0.86 & 0.48 & 0.69 & 0.43 \\
\hline
\end{tabular}

Av: Average; $n$ : number of samples; S.D.: standard deviation.

accuracy of analysis. The overall accuracy $(\% \mathrm{RSD})$ for trace elements and REE is $<20$.

\section{Geochemistry}

Chemical composition of rocks clearly points to two separate groups when abundances of some selected major element oxide and trace element are considered.

Group 1 mafic intrusives are characterized by relatively higher $\mathrm{SiO}_{2}(43.37-54.87 \%)$, lower $\mathrm{CaO}$ (5.88-14.89\%), lower $\mathrm{MgO}$ (4.5-17.26\% except one sample with $21.35 \% \mathrm{MgO}$ ) with relatively high $\mathrm{Ba}$ (mostly 704-1411 ppm) and higher differentiation index (13.66-33.43).

Group 2 ultramafic intrusives are characterized by low $\mathrm{SiO}_{2}$ (43.08-46.32\%), high $\mathrm{CaO}$ (13.66$14.89 \%)$, high $\mathrm{MgO}(21.92-25.88 \%$ ) with low $\mathrm{Ba}$ (208- $272 \mathrm{ppm})$ and lower differentiation index (4.72-7.66).

Chemical composition of Group 1 mafic rocks and Group 2 ultramafic rocks are presented in table 6 .

In order to understand the trend of variation of chemical attributes with magmatic differentiation, biaxial variation diagram with differentiation index (D.I.) is very useful. D.I. is plotted along $\mathrm{x}$ axis against different major element oxides (in $\mathrm{wt} \%$ ) and trace elements (in ppm) along y axis (figure 10). Plots of ultramafic and mafic rocks show linear variation trend with ultramafic rocks plotted as cluster at one end of the trend line. Groups 1 and 2 show positive correlation of $\mathrm{SiO}_{2}$, $\mathrm{Al}_{2} \mathrm{O}_{3}, \mathrm{Na}_{2} \mathrm{O}+\mathrm{K}_{2} \mathrm{O}$, Ba, $\mathrm{Sr}$ and $\mathrm{Y}$, but negative correlation of $\mathrm{CaO}$ and $\mathrm{MgO}$ with D.I.

To understand the co-genetic nature of the ultramafic and mafic rocks, $\mathrm{MgO}$ variation diagram is used (figure 11). $\mathrm{MgO}$ shows positive correlation with $\mathrm{CaO}, \mathrm{Cr}$ and $\mathrm{Ni}$ and negative correlation with $\mathrm{Na}_{2} \mathrm{O}, \mathrm{TiO}_{2}, \mathrm{Al}_{2} \mathrm{O}_{3}, \mathrm{Sr}$ and $\mathrm{Ba}$. The ultramafic rocks are plotted in cluster at one end of the trend line, whereas the plots of mafic rocks show systematic variation in all these biaxial variation diagrams.

Another diagram considering relative abundances of $\mathrm{MgO}, \mathrm{FeO}$ and total alkalies (AFM) is also important to discriminate calc-alkaline series from tholeiitic series with iron-enrichment trend. The samples from the study area, when plotted in AFM diagram show concentration of the ultramafic samples towards the $\mathrm{MgO}$ corner in the calc-alkaline field whereas the mafic samples show 
Table 4. Representative orthopyroxene and clinopyroxene composition of mafic and ultramafic rocks along North Puruliya Shear Zone.

\begin{tabular}{|c|c|c|c|c|c|c|c|c|}
\hline \multirow[b]{3}{*}{ Group } & \multicolumn{4}{|c|}{ Clinopyroxene } & \multicolumn{4}{|c|}{ Orthopyroxene } \\
\hline & \multicolumn{2}{|c|}{1} & \multicolumn{2}{|l|}{2} & \multicolumn{2}{|c|}{1} & \multicolumn{2}{|c|}{2} \\
\hline & $\overline{\mathrm{Av}(n=2)}$ & S.D. & $\overline{\mathrm{Av}(n=16)}$ & S.D. & $\overline{\mathrm{Av}(n=6)}$ & S.D. & $\overline{\mathrm{Av}}(n=23)$ & S.D. \\
\hline $\mathrm{SiO}_{2}$ & 51.43 & 0.68 & 51.59 & 1.19 & 51.52 & 0.83 & 46.22 & 15.99 \\
\hline $\mathrm{TiO}_{2}$ & 0.28 & 0.11 & 0.27 & 0.21 & 0.25 & 0.14 & 0.27 & 0.19 \\
\hline $\mathrm{Al}_{2} \mathrm{O}_{3}$ & 2.45 & 0.71 & 2.60 & 1.56 & 2.09 & 0.68 & 2.51 & 1.47 \\
\hline $\mathrm{FeO}$ & 8.62 & 2.50 & 6.16 & 1.36 & 9.80 & 1.52 & 5.88 & 1.95 \\
\hline $\mathrm{Cr}_{2} \mathrm{O}_{3}$ & 0.12 & 0.12 & 0.25 & 0.16 & 0.06 & 0.04 & 0.24 & 0.14 \\
\hline $\mathrm{MnO}$ & 0.20 & 0.06 & 0.13 & 0.07 & 0.20 & 0.05 & 0.13 & 0.07 \\
\hline $\mathrm{NiO}$ & 0.02 & 0.04 & 0.01 & 0.02 & 0.00 & 0.00 & 0.01 & 0.02 \\
\hline $\mathrm{MgO}$ & 13.66 & 1.25 & 15.42 & 1.28 & 13.41 & 1.14 & 13.82 & 4.59 \\
\hline $\mathrm{CaO}$ & 24.04 & 0.92 & 22.50 & 2.65 & 24.49 & 0.68 & 20.37 & 7.00 \\
\hline $\mathrm{Na}_{2} \mathrm{O}$ & 0.54 & 0.06 & 0.60 & 0.23 & 0.51 & 0.06 & 0.56 & 0.26 \\
\hline $\mathrm{K}_{2} \mathrm{O}$ & 0.01 & 0.01 & 0.02 & 0.07 & 0.01 & 0.01 & 0.03 & 0.06 \\
\hline $\mathrm{TSi}$ & 1.88 & 0.02 & 1.90 & 0.05 & 1.88 & 0.01 & 1.70 & 0.59 \\
\hline TAl & 0.09 & 0.02 & 0.10 & 0.05 & 0.09 & 0.03 & 0.09 & 0.05 \\
\hline $\mathrm{TFe}_{3}$ & 0.02 & 0.02 & 0.00 & 0.00 & 0.03 & 0.02 & 0.00 & 0.01 \\
\hline M1Al & 0.01 & 0.02 & 0.01 & 0.02 & 0.00 & 0.00 & 0.02 & 0.02 \\
\hline M1Ti & 0.01 & 0.00 & 0.01 & 0.01 & 0.01 & 0.00 & 0.01 & 0.01 \\
\hline $\mathrm{M}_{1 F e}$ & 0.12 & 0.04 & 0.08 & 0.05 & 0.14 & 0.01 & 0.08 & 0.05 \\
\hline $\mathrm{M} 1 F e_{2}$ & 0.10 & 0.06 & 0.05 & 0.05 & 0.11 & 0.05 & 0.06 & 0.04 \\
\hline $\mathrm{M} 1 \mathrm{Cr}$ & 0.00 & 0.00 & 0.01 & 0.00 & 0.00 & 0.00 & 0.01 & 0.00 \\
\hline $\mathrm{M} 1 \mathrm{Mg}$ & 0.75 & 0.07 & 0.83 & 0.04 & 0.73 & 0.06 & 0.74 & 0.25 \\
\hline $\mathrm{M} 1 \mathrm{Ni}$ & 0.00 & 0.00 & 0.00 & 0.00 & 0.00 & 0.00 & 0.00 & 0.00 \\
\hline $\mathrm{M} 2 \mathrm{Mg}$ & 0.00 & 0.00 & 0.02 & 0.04 & 0.00 & 0.00 & 0.02 & 0.04 \\
\hline $\mathrm{M}_{2} \mathrm{Fe}_{2}$ & 0.02 & 0.02 & 0.05 & 0.06 & 0.01 & 0.01 & 0.05 & 0.06 \\
\hline $\mathrm{M} 2 \mathrm{Mn}$ & 0.01 & 0.00 & 0.00 & 0.00 & 0.01 & 0.00 & 0.00 & 0.00 \\
\hline $\mathrm{M} 2 \mathrm{Ca}$ & 0.94 & 0.03 & 0.89 & 0.10 & 0.96 & 0.02 & 0.80 & 0.28 \\
\hline $\mathrm{M} 2 \mathrm{Na}$ & 0.04 & 0.00 & 0.04 & 0.02 & 0.04 & 0.00 & 0.04 & 0.02 \\
\hline $\mathrm{M} 2 \mathrm{~K}$ & 0.00 & 0.00 & 0.00 & 0.00 & 0.00 & 0.00 & 0.00 & 0.00 \\
\hline Sum_cat & 4.00 & 0.00 & 4.00 & 0.00 & 4.00 & 0.00 & 3.58 & 1.26 \\
\hline $\mathrm{Ca}$ & 52.02 & 1.73 & 48.26 & 5.94 & 52.79 & 1.07 & 43.74 & 15.11 \\
\hline $\mathrm{Mg}$ & 41.11 & 3.55 & 45.96 & 3.41 & 40.19 & 2.90 & 41.20 & 13.70 \\
\hline $\mathrm{Fe}_{2} \mathrm{Mn}$ & 6.87 & 3.07 & 5.79 & 3.64 & 7.02 & 3.67 & 5.65 & 3.41 \\
\hline JD1 & 0.65 & 1.05 & 0.72 & 1.01 & 0.00 & 0.00 & 0.79 & 0.91 \\
\hline AE1 & 1.46 & 0.88 & 1.63 & 1.07 & 2.00 & 0.25 & 1.54 & 1.00 \\
\hline CFTS1 & 5.42 & 0.94 & 3.64 & 2.44 & 5.94 & 0.51 & 3.58 & 2.36 \\
\hline CTTS1 & 0.43 & 0.17 & 0.40 & 0.32 & 0.38 & 0.21 & 0.40 & 0.29 \\
\hline CATS1 & 0.00 & 0.00 & 0.06 & 0.22 & 0.00 & 0.00 & 0.06 & 0.21 \\
\hline WO1 & 45.25 & 1.22 & 43.12 & 5.57 & 45.59 & 1.21 & 38.93 & 13.53 \\
\hline EN1 & 40.38 & 3.41 & 44.98 & 3.49 & 39.52 & 2.85 & 40.33 & 13.42 \\
\hline FS1 & 6.42 & 3.00 & 5.46 & 3.53 & 6.57 & 3.63 & 5.34 & 3.30 \\
\hline $\mathrm{Q}$ & 1.81 & 0.01 & 1.84 & 0.07 & 1.80 & 0.01 & 1.65 & 0.57 \\
\hline $\mathrm{J}$ & 0.08 & 0.01 & 0.09 & 0.03 & 0.07 & 0.01 & 0.08 & 0.04 \\
\hline WO & 48.15 & 0.64 & 46.05 & 5.27 & 48.06 & 0.62 & 41.58 & 14.46 \\
\hline $\mathrm{EN}$ & 38.12 & 3.96 & 43.92 & 3.51 & 36.58 & 2.37 & 39.35 & 13.02 \\
\hline FS & 13.73 & 3.83 & 10.04 & 2.18 & 15.37 & 2.66 & 9.56 & 3.16 \\
\hline
\end{tabular}

Av: Average; $n$ : number of samples; S.D.: standard deviation.

somewhat curvilinear variation pattern towards hence are used as normalizing factors for con the alkali end through $\mathrm{FeO}^{\mathrm{t}}$ corner in the tholeiitic sidering the distribution pattern of the REE. In field (figure 12).

REE contents of carbonaceous chondritic meteorites are considered primitive, i.e., non-evolved, chondrite-normalized REE diagram (figure 13a, b REE values of Type 1 carbonaceous chondrite are quoted from Taylor and McLennan 1985), the REE 
Table 5. Amphibole, biotite and opaque compositions of mafic and ultramafic rocks along North Puruliya Shear Zone.

\begin{tabular}{|c|c|c|c|c|c|c|c|}
\hline \multirow[b]{3}{*}{ Group } & \multirow{2}{*}{\multicolumn{2}{|c|}{$\frac{\text { Amphibole }}{2}$}} & \multirow[b]{3}{*}{ Group } & \multicolumn{4}{|c|}{ Biotite } \\
\hline & & & & \multicolumn{2}{|c|}{1} & \multicolumn{2}{|c|}{2} \\
\hline & $\operatorname{Av}(n=10)$ & S.D. & & $\operatorname{Av}(n=4)$ & S.D. & $\operatorname{Av}(n=16)$ & S.D. \\
\hline $\mathrm{SiO}_{2}$ & 44.01 & 2.74 & $\mathrm{SiO}_{2}$ & 38.87 & 2.46 & 35.42 & 5.85 \\
\hline $\mathrm{TiO}_{2}$ & 1.15 & 0.27 & $\mathrm{TiO}_{2}$ & 3.55 & 1.71 & 3.86 & 1.10 \\
\hline $\mathrm{Al}_{2} \mathrm{O}_{3}$ & 11.42 & 1.83 & $\mathrm{Al}_{2} \mathrm{O}_{3}$ & 13.17 & 0.38 & 14.68 & 1.02 \\
\hline $\mathrm{FeO}$ & 9.48 & 3.82 & $\mathrm{FeO}$ & 17.07 & 1.22 & 11.46 & 3.93 \\
\hline $\mathrm{Cr}_{2} \mathrm{O}_{3}$ & 0.13 & 0.15 & $\mathrm{Cr}_{2} \mathrm{O}_{3}$ & 0.11 & 0.07 & 0.24 & 0.14 \\
\hline $\mathrm{MnO}$ & 0.10 & 0.06 & $\mathrm{MnO}$ & 0.17 & 0.16 & 0.03 & 0.03 \\
\hline $\mathrm{MgO}$ & 15.25 & 2.60 & $\mathrm{MgO}$ & 11.19 & 3.12 & 16.96 & 3.22 \\
\hline $\mathrm{CaO}$ & 12.20 & 0.54 & $\mathrm{CaO}$ & 6.27 & 7.23 & 0.01 & 0.02 \\
\hline $\mathrm{Na}_{2} \mathrm{O}$ & 1.67 & 0.99 & $\mathrm{Na}_{2} \mathrm{O}$ & 1.15 & 1.18 & 0.31 & 0.21 \\
\hline $\mathrm{K}_{2} \mathrm{O}$ & 0.62 & 0.44 & $\mathrm{~K}_{2} \mathrm{O}$ & 5.21 & 5.46 & 9.60 & 0.19 \\
\hline $\mathrm{NiO}$ & 0.05 & 0.07 & $\mathrm{NiO}$ & 0.00 & 0.00 & 0.03 & 0.06 \\
\hline \multirow[t]{2}{*}{$\mathrm{H}_{2} \mathrm{O}$} & 2.03 & 0.03 & & & & & \\
\hline & & & $\mathrm{Si}$ & 5.01 & 0.41 & 4.42 & 0.61 \\
\hline TSi & 6.26 & 0.40 & AlIV & 2.00 & 0.03 & 2.18 & 0.20 \\
\hline TAl & 1.74 & 0.40 & AlVI & 0.00 & 0.00 & 0.00 & 0.00 \\
\hline $\mathrm{TFe}_{3}$ & 0.00 & 0.00 & $\mathrm{Ti}$ & 0.34 & 0.16 & 0.37 & 0.11 \\
\hline $\mathrm{TTi}$ & 0.00 & 0.00 & $\mathrm{Fe}_{2}$ & 1.84 & 0.16 & 1.21 & 0.44 \\
\hline Sum_T & 8.00 & 0.00 & $\mathrm{Cr}$ & 0.01 & 0.01 & 0.02 & 0.01 \\
\hline $\mathrm{CAl}$ & 0.17 & 0.12 & $\mathrm{Mn}$ & 0.02 & 0.02 & 0.00 & 0.00 \\
\hline $\mathrm{CCr}$ & 0.01 & 0.02 & $\mathrm{Mg}$ & 2.14 & 0.56 & 3.19 & 0.67 \\
\hline $\mathrm{CFe}_{3}$ & 1.13 & 0.45 & $\mathrm{Ba}$ & 0.00 & 0.00 & 0.00 & 0.00 \\
\hline $\mathrm{CTi}$ & 0.12 & 0.03 & $\mathrm{Ca}$ & 0.88 & 1.01 & 0.00 & 0.00 \\
\hline $\mathrm{CMg}$ & 3.23 & 0.55 & $\mathrm{Na}$ & 0.29 & 0.30 & 0.08 & 0.05 \\
\hline $\mathrm{CFe}_{2}$ & 0.00 & 0.00 & $\mathrm{~K}$ & 0.84 & 0.88 & 1.55 & 0.12 \\
\hline CMn & 0.01 & 0.01 & & & & & \\
\hline $\mathrm{CCa}$ & 0.32 & 0.19 & & & & & \\
\hline Sum_C & 5.00 & 0.00 & Mg no. & 0.53 & 0.09 & 0.72 & 0.11 \\
\hline $\mathrm{BMg}$ & 0.00 & 0.00 & & & & & \\
\hline $\mathrm{BFe}_{2}$ & 0.00 & 0.00 & & & & & \\
\hline BMn & 0.00 & 0.00 & & & & & \\
\hline $\mathrm{BCa}$ & 1.54 & 0.27 & & Opaque & & & \\
\hline $\mathrm{BNa}$ & 0.46 & 0.27 & & $\operatorname{Av}(n=10)$ & S.D. & & \\
\hline Sum_B & 2.00 & 0.00 & $\mathrm{SiO}_{2}$ & 4.02 & 12.50 & & \\
\hline $\mathrm{ACa}$ & 0.00 & 0.00 & $\mathrm{TiO}_{2}$ & 20.79 & 25.61 & & \\
\hline $\mathrm{ANa}$ & 0.00 & 0.00 & $\mathrm{Al}_{2} \mathrm{O}_{3}$ & 5.58 & 13.45 & & \\
\hline $\mathrm{AK}$ & 0.11 & 0.08 & $\mathrm{FeO}$ & 57.72 & 26.24 & & \\
\hline Sum_A & 0.11 & 0.08 & $\mathrm{Cr}_{2} \mathrm{O}_{3}$ & 0.65 & 1.05 & & \\
\hline Sum_cat & 15.11 & 0.08 & $\mathrm{MnO}$ & 0.55 & 0.71 & & \\
\hline $\mathrm{CCl}$ & 0.00 & 0.00 & $\mathrm{MgO}$ & 3.07 & 5.45 & & \\
\hline $\mathrm{CF}$ & 0.00 & 0.00 & $\mathrm{CaO}$ & 1.20 & 3.68 & & \\
\hline $\mathrm{OH}$ & & & $\mathrm{Na}_{2} \mathrm{O}$ & 0.21 & 0.59 & & \\
\hline Sum_oxy & 22.73 & 0.18 & $\mathrm{~K}_{2} \mathrm{O}$ & 0.19 & 0.57 & & \\
\hline Mg no. & 0.74 & 0.11 & $\mathrm{NiO}$ & 0.03 & 0.09 & & \\
\hline
\end{tabular}

Av: Average, $n$ : number of samples, S.D.: standard deviation.

variation pattern of mafic (Group 1) and ultramafic (Group 2) intrusives has been depicted. All the samples of Group 1 show LREE-enriched character with negative Eu anomaly, whereas one sample shows the same pattern but with positive
Eu anomaly. Among Group 2, two samples show LREE-enriched pattern, one with unusual negative $\mathrm{Eu}$ anomaly and the other with no $\mathrm{Eu}$ anomaly but with positive $\mathrm{Tb}$ anomaly. Another sample of Group 2 shows somewhat flat REE pattern. 
Table 6. Whole rock chemical composition of mafic and ultramafic rocks along North Puruliya Shear Zone.

\begin{tabular}{|c|c|c|c|c|c|c|c|c|c|c|c|c|c|c|}
\hline \multirow{2}{*}{$\begin{array}{l}\text { Group } \\
\text { Sample }\end{array}$} & \multicolumn{9}{|c|}{1} & \multicolumn{3}{|c|}{2} & \multicolumn{2}{|c|}{ Standard } \\
\hline & 119 & 120 & $70 \mathrm{D}$ & 122 & L7 & $57 \mathrm{~A}$ & $58 \mathrm{~A}$ & $58 \mathrm{~B}$ & $27 \mathrm{~B}$ & 124 & $443 \mathrm{II}$ & 121 & $\mathrm{BHVO}^{1}$ & $\mathrm{BHVO}^{2}$ \\
\hline $\mathrm{iO}_{2}$ & 50.25 & 51.97 & 43.94 & 43.78 & 43.4 & 47.68 & 54.9 & 51 & 50 & 43.08 & 45.32 & 46.32 & 49.63 & 49.89 \\
\hline $\mathrm{TiO}_{2}$ & 1.85 & 1.06 & 1.85 & 1.97 & 0.87 & 0.92 & 0.42 & 0.3 & 0.74 & 0.48 & 0.85 & 0.65 & 2.71 & 2.67 \\
\hline $\mathrm{Al}_{2} \mathrm{O}_{3}$ & 17.78 & 12.9 & 13.02 & 14.27 & 8 & 17.88 & 13.8 & 12.2 & 5.49 & 5.61 & 6.82 & 6.31 & 13.8 & 13.71 \\
\hline $\mathrm{Fe}_{2} \mathrm{O}_{3}$ & 0.87 & 0.87 & 2.57 & 2.81 & 1.24 & 0.94 & 0.78 & 0.72 & 1.07 & 0.66 & 0.82 & 0.82 & 10.39 & 10.36 \\
\hline $\mathrm{FeO}$ & 4.95 & 4.91 & 14.57 & 15.91 & 11.2 & 8.48 & 7.05 & 6.49 & 9.66 & 3.75 & 4.61 & 4.64 & 1.83 & 1.83 \\
\hline $\mathrm{MnO}$ & 0.1 & 0.1 & 0.31 & 0.2 & 0.16 & 0.08 & 0.12 & 0.12 & 0.16 & 0.09 & 0.10 & 0.10 & 0.16 & 0.11 \\
\hline $\mathrm{MgO}$ & 6.31 & 11.53 & 7.07 & 7.54 & 21.4 & 4.5 & 9.35 & 15 & 17.3 & 25.88 & 21.92 & 22.80 & 7.23 & 7.12 \\
\hline $\mathrm{CaO}$ & 10.68 & 10.5 & 13.47 & 10.6 & 5.88 & 10.08 & 8.89 & 11.7 & 9.18 & 14.89 & 14.14 & 13.66 & 11.41 & 11.33 \\
\hline $\mathrm{Na}_{2} \mathrm{O}$ & 2 & 1.36 & 1.34 & 1.54 & 1.32 & 2.47 & 2.37 & 1.48 & 0.79 & 0.52 & 0.51 & 0.56 & 2.26 & 2.21 \\
\hline $\mathrm{K}_{2} \mathrm{O}$ & 1.14 & 0.95 & 0.4 & 0.08 & 1.79 & 0.94 & 1.7 & 0.37 & 0.98 & 0.46 & 0.78 & 0.51 & 0.52 & 0.011 \\
\hline $\mathrm{P}_{2} \mathrm{O}_{5}$ & 1.7 & 1.27 & 0.21 & 0.05 & 0.54 & 0.35 & 0.48 & 0.05 & 0.39 & 0.31 & 0.30 & 0.31 & JB- $2^{2}$ & $\mathrm{JB}-2^{3}$ \\
\hline $\mathrm{Ba}$ & 878.72 & 704.40 & 768.33 & 19.98 & 146 & 942 & 1411 & 261 & 785 & 272.06 & 208.14 & 272.47 & 208 & 208.14 \\
\hline $\mathrm{Rb}$ & 136.78 & 88.46 & 26.73 & 2.35 & 47 & 24 & 41 & 8 & 27 & 32.75 & 6.12 & 39.06 & 6.2 & 6.121 \\
\hline $\mathrm{Sr}$ & 1188.16 & 817.10 & 559.35 & 271.31 & 572 & 1650 & 1192 & 293 & 310 & 254.88 & 174.35 & 349.34 & 178 & 174.37 \\
\hline $\mathrm{Y}$ & 62.85 & 46.44 & 38.34 & 9.91 & 13 & 25 & 33 & 20 & 13 & 18.58 & 24.31 & 23.95 & 24.9 & 24.311 \\
\hline $\mathrm{Zr}$ & 65.58 & 23.60 & 14.52 & 22.23 & 154 & 154 & 143 & 56 & 102 & 107.59 & 51.20 & 135.94 & 51.4 & 51.198 \\
\hline $\mathrm{Nb}$ & 36.39 & 21.76 & 14.97 & 78.16 & 16 & 7 & 6 & 2 & 7 & 8.49 & 0.75 & 10.40 & 0.8 & 0.753 \\
\hline Th & 9.87 & 7.88 & 1.93 & 0.45 & & & & & & 7.06 & 0.30 & 4.61 & 0.33 & 0.303 \\
\hline $\mathrm{Pb}$ & 2.72 & 3.30 & 3.71 & 1.18 & 12 & 8 & 10 & 10 & 9 & 2.19 & 5.07 & 3.99 & 5.4 & 5.072 \\
\hline $\mathrm{Ga}$ & 26.15 & 17.21 & 12.60 & 18.33 & & & & & & 7.34 & 16.56 & 9.41 & 17 & 16.558 \\
\hline $\mathrm{Ni}$ & 65.09 & 187.60 & 42.29 & 139.60 & 548 & 120 & 53 & 167 & 263 & 584.68 & 13.98 & 441.12 & 14.2 & 13.976 \\
\hline $\mathrm{V}$ & 301.22 & 197.40 & 155.51 & 299.70 & & & & & & 166.42 & 561.00 & 188.14 & 578 & 561 \\
\hline $\mathrm{Cr}$ & 224.66 & 759.30 & 76.52 & 304.47 & 1767 & 210 & 92 & 1052 & 1434 & 3968.03 & 26.47 & 1738.19 & 27.4 & 26.47 \\
\hline Hf & 1.75 & 1.13 & 1.00 & 0.72 & & & & & & 2.34 & 1.46 & 3.40 & 1.42 & 1.455 \\
\hline Cs & 1.33 & 2.79 & 0.86 & 1.28 & & & & & & 0.67 & 0.91 & 2.39 & 0.9 & 0.91 \\
\hline $\mathrm{Sc}$ & 34.56 & 41.38 & 31.73 & 36.20 & & & & & & 44.76 & 52.80 & 51.49 & 54.4 & 52.796 \\
\hline $\mathrm{Ta}$ & 0.69 & 0.27 & 1.95 & 11.82 & & & & & & 1.93 & 0.20 & 0.36 & 0.2 & 0.2 \\
\hline $\mathrm{Co}$ & 58.55 & 63.18 & 56.21 & 112.69 & & 32 & 62 & 319 & 59 & 91.87 & 37.92 & 99.50 & 39.8 & 37.92 \\
\hline $\mathrm{La}$ & 355.56 & 102.00 & 64.14 & 2.83 & & & & & & 42.88 & 2.34 & 36.31 & 2.37 & 2.341 \\
\hline $\mathrm{Ce}$ & 355.56 & 195.20 & 140.48 & 5.73 & & & & & & 87.30 & 6.52 & 72.36 & 6.77 & 6.519 \\
\hline $\operatorname{Pr}$ & 38.10 & 20.76 & 14.56 & 0.70 & & & & & & 9.49 & 0.92 & 8.09 & 0.96 & 0.919 \\
\hline $\mathrm{Nd}$ & 171.16 & 94.94 & 72.90 & 4.05 & & & & & & 44.81 & 6.46 & 39.72 & 6.7 & 6.456 \\
\hline $\mathrm{Sm}$ & 26.61 & 15.78 & 13.52 & 1.16 & & & & & & 7.63 & 2.25 & 7.65 & 2.25 & 2.248 \\
\hline $\mathrm{Eu}$ & 5.61 & 4.06 & 3.26 & 0.96 & & & & & & 1.97 & 0.85 & 0.06 & 0.86 & 0.854 \\
\hline Gd & 24.44 & 14.65 & 21.37 & 1.36 & & & & & & 6.79 & 3.24 & 6.90 & 3.28 & 3.342 \\
\hline $\mathrm{Tb}$ & 2.40 & 1.56 & 2.24 & 0.22 & & & & & & 7.06 & 0.63 & 0.76 & 0.62 & 0.626 \\
\hline Dy & 11.61 & 8.41 & 7.25 & 1.62 & & & & & & 3.46 & 3.68 & 4.34 & 3.66 & 3.68 \\
\hline Ho & 2.03 & 1.52 & 1.33 & 0.36 & & & & & & 0.61 & 0.78 & 0.78 & 0.81 & 0.779 \\
\hline $\mathrm{Er}$ & 5.40 & 4.00 & 4.92 & 0.93 & & & & & & 1.58 & 2.64 & 2.07 & 2.63 & 2.642 \\
\hline $\mathrm{Tm}$ & 0.51 & 0.42 & 0.59 & 0.11 & & & & & & 0.16 & 0.45 & 0.22 & 0.45 & 0.454 \\
\hline $\mathrm{Yb}$ & 2.73 & 2.28 & 3.55 & 0.60 & & & & & & 0.90 & 2.55 & 1.18 & 2.51 & 2.55 \\
\hline $\mathrm{Lu}$ & 0.57 & 0.51 & 0.48 & 0.14 & & & & & & 0.19 & 0.38 & 0.26 & 0.39 & 0.379 \\
\hline $\mathrm{U}$ & 0.64 & 0.72 & 0.30 & 0.17 & & & & & & 0.71 & 0.16 & 0.63 & 0.16 & 0.155 \\
\hline D.I. & 29.57 & 22.48 & 13.86 & 13.66 & 22.7 & 33.43 & 37.1 & 15.3 & 17.8 & 4.72 & 6.96 & 7.66 & & \\
\hline
\end{tabular}

D.I.: Differentiation index; ${ }^{1}$ : certified; ${ }^{2}$ : measured; ${ }^{3}$ : analysed.

\section{Discussion}

\subsection{Mineralogical and geochemical evolution of the mafic-ultramafic suite}

Mafic rocks of the study area occur either in isolation or in association with the ultramafic rocks.
Mineral composition of both varieties is more or less same, only modal proportion and composition of the constituent minerals vary. Ultramafic rocks have less $(<10 \%)$ amount of more calcic $\left(\mathrm{An}_{76}\right)$ plagioclase, more $\mathrm{Mg}$-rich olivine $\left(\mathrm{Fo}_{76}\right), \mathrm{Mg}$-rich orthopyroxene $\left(\mathrm{En}_{80}\right), \mathrm{Mg}-\mathrm{Fe}-\mathrm{rich}$ clinopyroxene $\left(\mathrm{Wo}_{50} \mathrm{En}_{43} \mathrm{Fs}_{7}\right)$ and Mg-rich biotite (Mg no. 87), 

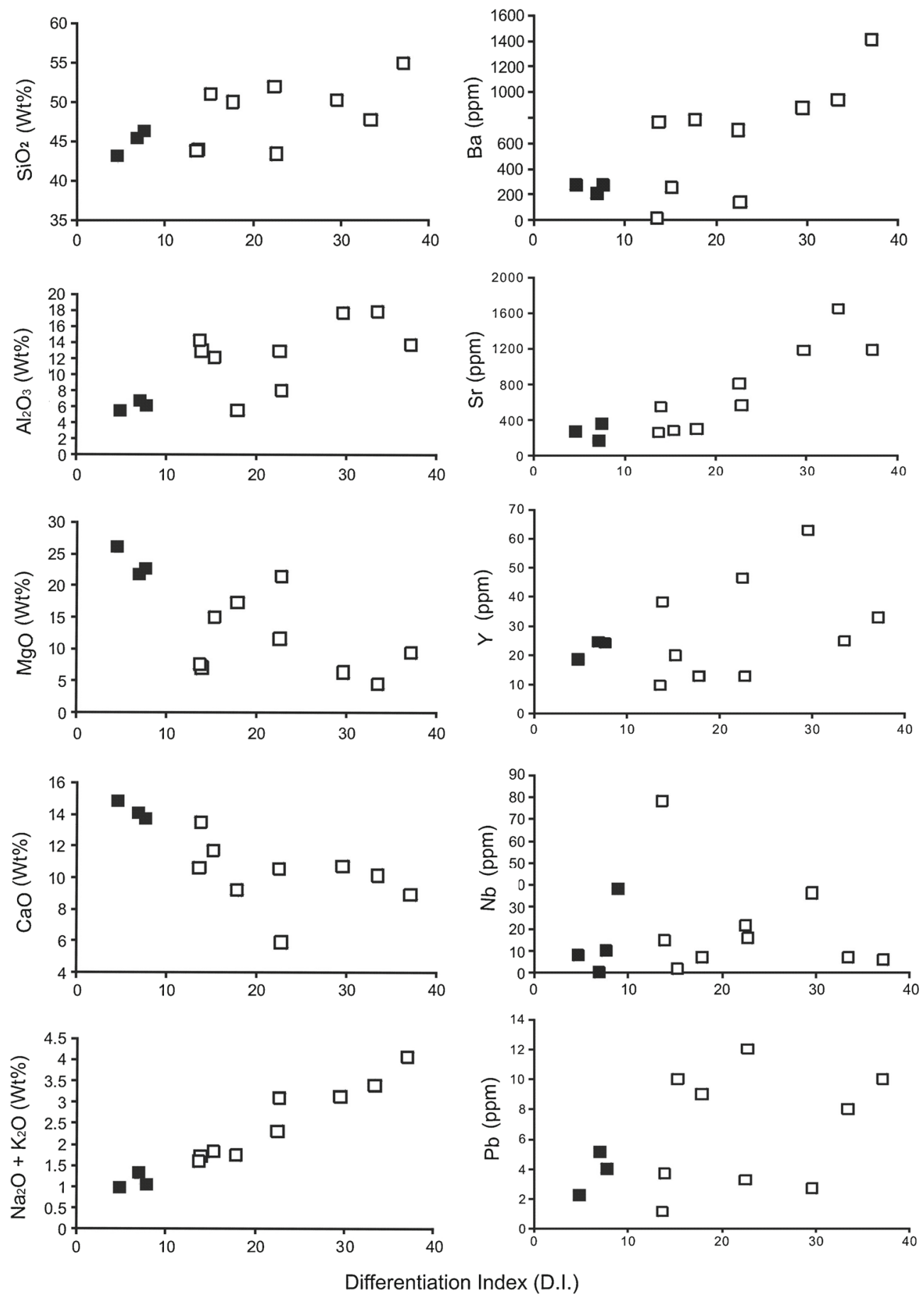

Figure 10. Differentiation index (D.I.) variation diagrams of mafic and ultramafic rocks occurring along North Puruliya Shear Zone. Void squares represent mafic rocks (Group 1) and solid squares represent ultramafic rocks (Group 2) of the study area.

compared to mafic (Plag: $\mathrm{An}_{43}, \mathrm{Ol}: \mathrm{Fo}_{74}, \mathrm{Opx}$ : $\left.\mathrm{En}_{72}, \mathrm{Cpx}: \mathrm{Wo}_{48} \mathrm{En}_{44} \mathrm{Fs}_{8}\right)$ counterpart. The mineralogical correlation indicates a possible genetic link between the two groups. $\mathrm{Mg}$ no. of the rocks varies widely from 92 in ultramafic to 46 in mafic rocks and D.I. from 4.7 in ultramafic to 37.1 in mafic rocks, which signifies that a Mg-rich mother magma with lower D.I. is gradually differentiated and evolved to a less Mg-rich melt of mafic composition after separation of Mg-rich ultramafic part. Trace element distribution diagram shows enrichment of $\mathrm{Ba}$ and $\mathrm{Ce}$ in the mafic rocks which can be accumulated in the later formed plagioclase feldspar lattice. Rb is nearly constant in ultramafic rocks but it varies widely in mafic rocks which may be due to contamination of the residual melt with 

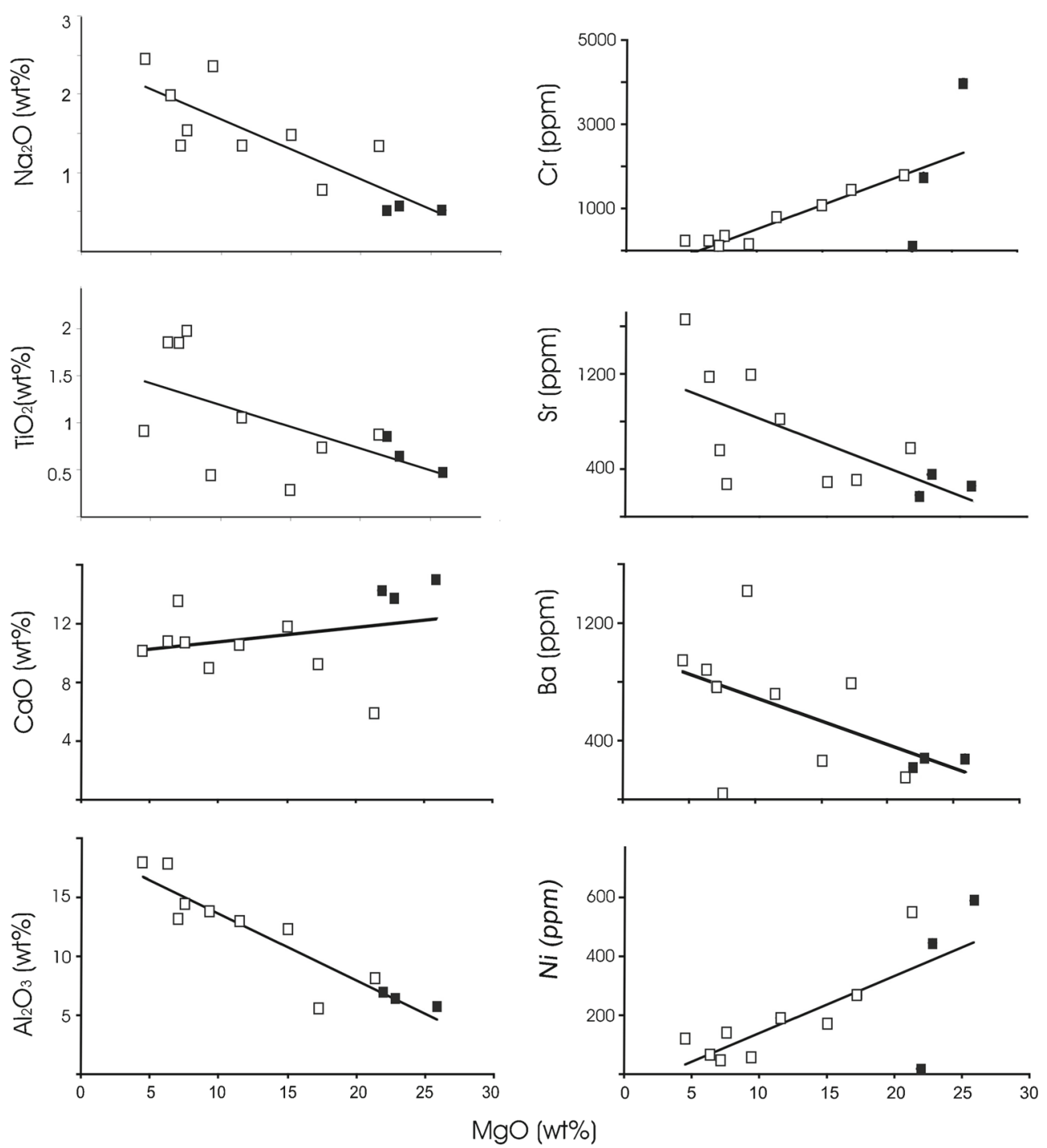

Figure 11. MgO variation diagrams of mafic and ultramafic rocks occurring along North Puruliya Shear Zone. Void squares represent mafic rocks (Group 1) and solid squares represent ultramafic rocks (Group 2) of the study area.

the granitic country rocks. In the biaxial variation diagrams using D.I. (figure 10) and $\mathrm{MgO}$ wt\% (figure 11) against other oxides and trace elements, ultramafic rocks are clustered at one end of a nearly linear array defined by the mafic rocks which indicates fractionation-controlled differentiation pattern and ultramafic rock as crystal cumulates from a mafic parent melt and mafic rock as the product from the residual melt. Thus, a genetic link may be established between ultramafic and mafic rocks of the study area. AFM diagram also show clusters of ultramafic rocks at the $\mathrm{Mg}$ corner and a curvilinear pattern produced by the mafic rocks towards the alkali end nearing the Fe end, which again points to a middle stage iron enrichment and a final stage of alkali enrichment. Field occurrence, mineralogical and geochemical data might suggest that ultramafic rocks are the early crystal fractionates of a Mg-rich primitive magma and mafic part represent the residual melt fraction.
The magmatic differentiation process is controlled by fractional crystallization of the parent magma by the fractionation of early formed minerals, e.g., olivine, clinopyroxene and plagioclase. The mechanism of fractional crystallization is clearly demonstrated by D.I. and $\mathrm{MgO}$ variation diagrams (figures 10,11). Gradual depletion of $\mathrm{MgO}, \mathrm{CaO}$ and enrichment in $\mathrm{SiO}_{2}, \mathrm{Al}_{2} \mathrm{O}_{3}$, total alkali and $\mathrm{Ba}, \mathrm{Sr}$ and $\mathrm{Y}$ against D.I. is conspiquous. Also conspiquous is the depletion of $\mathrm{Na}_{2} \mathrm{O}$, $\mathrm{TiO}_{2}, \mathrm{Al}_{2} \mathrm{O}_{3}, \mathrm{Ba}$, Sr and enrichment of $\mathrm{CaO}$, Ni, $\mathrm{Cr}$ against $\mathrm{MgO}$. These chemical variations point to olivine, clinopyroxene and calcic plagioclase fractionation.

Mafic rocks generally have low abundance of $\mathrm{Rb}$ and $\mathrm{Zr}$, whereas granitic rocks or upper crustal rocks have greater abundance of $\mathrm{Rb}$ and $\mathrm{Zr}$. The mafic rocks of the present study area have a wide range of $\mathrm{Rb}(2.3-136.8 \mathrm{ppm})$ and $\mathrm{Zr}\left(22.2^{-}\right.$ $154 \mathrm{ppm}$ ) abundance. This high value of $\mathrm{Rb}$ and 


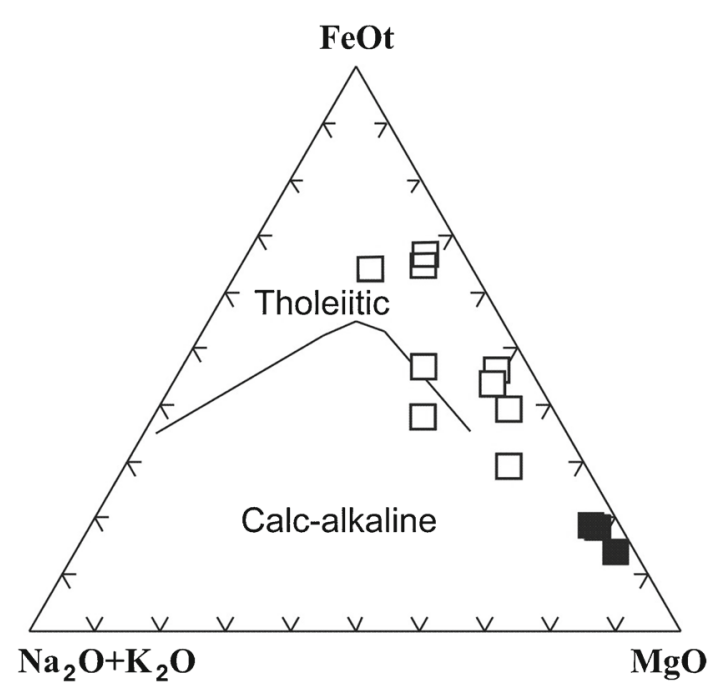

Figure 12. A $\left(\mathrm{Na}_{2} \mathrm{O}+\mathrm{K}_{2} \mathrm{O}\right)-\mathrm{F}\left(\mathrm{FeO}^{\mathrm{t}}\right)-\mathrm{M}(\mathrm{MgO})$ diagram (after Irvine and Baragar 1971) of the mafic and ultramafic rocks. Void squares represent mafic rocks (Group 1) and solid squares represent ultramafic rocks (Group 2) of the study area.

Zr concentration in mafic intrusive rocks may be attributed to crustal contamination. $\mathrm{Rb}$ and $\mathrm{Zr}$ are taken to quantify the extent of crustal contamination.

The mafic-ultramafic rocks of the study area have geochemical signature similar to the arc lava (Winter 2001). These geochemical characteristics (LILE enrichment, HFSE depletion) were possibly inherited partly from the fertile mantle source and partly by crustal contamination. If the arc lavas suffer crustal contamination at higher level crustal magma chamber or during their emplacement, the LILE enrichment becomes more pronounced. Some of the trace elements like $\mathrm{Sr}, \mathrm{Rb}$, $\mathrm{Ba}, \mathrm{Zr}$ show wide range of variation in their abundance in the mafic-ultramafic rocks of present study, which might be considered as the result of input comes from composition of source mantle and fractionating crustal material. Variation in abundance of elements like $\mathrm{Ba}, \mathrm{Sr}$ are considered as result of variable input from subduction zone components (subduction zone fluid, subducted sediments, subducted lithospheric plate). Elements like $\mathrm{Rb}, \mathrm{Zr}$ with their variable abundance probably indicate effect of crustal contamination during emplacement of magma. In order to quantify the degree of crustal contamination in different members of mafic-ultramafic suite, two methods have been followed. In the first method, the sample with least $\mathrm{Rb}$ is taken as least contaminated or uncontaminated and other samples are normalized with respect to this sample. The result is expressed in the form of contamination
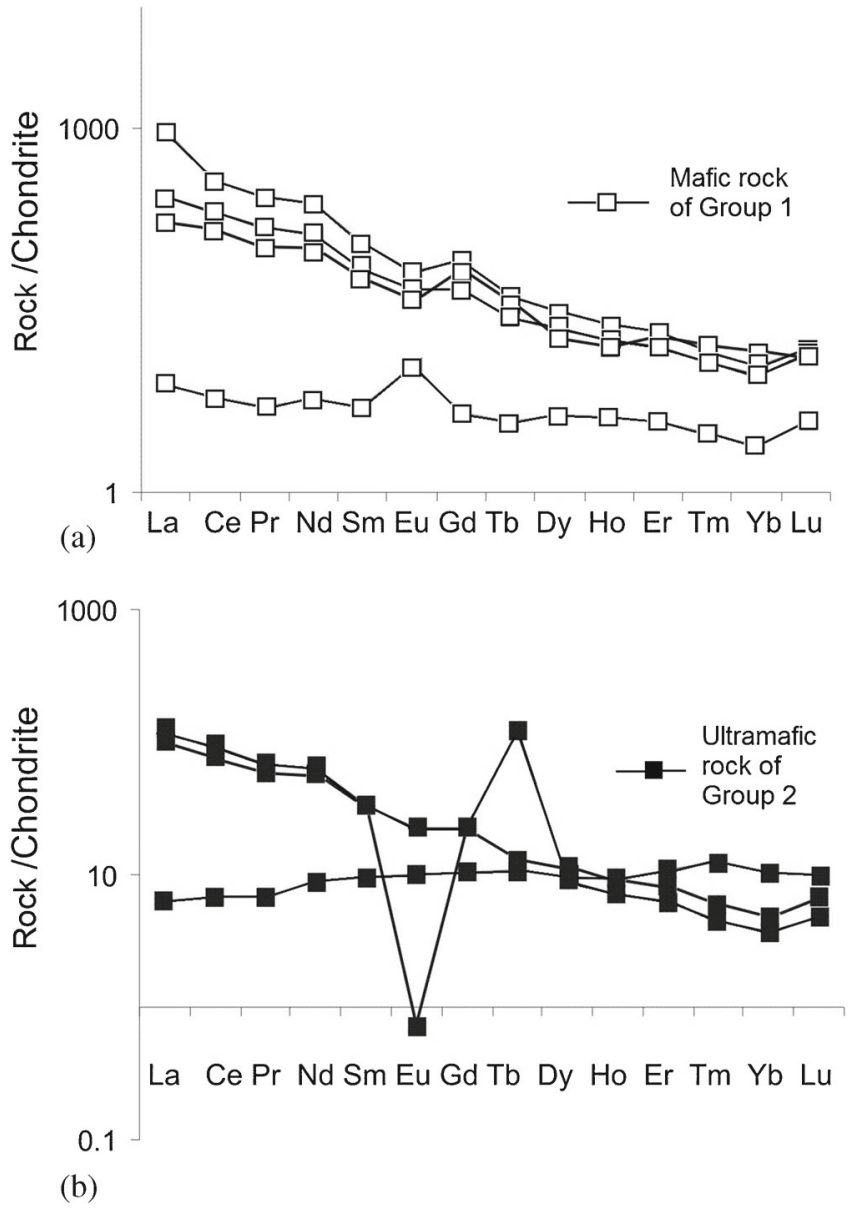

Figure 13. Chondrite normalized REE variation diagram of mafic and ultramafic rocks occurring along North Puruliya Shear Zone in the study area. REE values of Type 1 Carbonaceous Chondrite (volatile free: $1.5 \times$ Original data) taken from Taylor and McLennan (1985). Chondrite normalized REE variation diagram of the (a) mafic rocks of Group 1 and (b) ultramafic rocks of Group 2.

index (C.I.), where C.I. (for Rb) $=(\mathrm{Rb}$ in sample $\mathrm{Rb}$ in least-contaminated sample)/ $\mathrm{Rb}$ in leastcontaminated sample (Rollinson 1993). C.I. for Rb is $0-57.2$ in Group 1 and 1.6-12.6 in Group 2. In the second method, composition of granite country rock is used to assess the degree of granitic contamination, as per following equation: $\mathrm{C}_{\text {sample }}^{\mathrm{Rb}}=$ $\mathrm{XC}_{\mathrm{Gr}}^{\mathrm{Rb}}+(1-\mathrm{X}) \mathrm{C}_{\mathrm{PM}}^{\mathrm{Rb}}$, where $\mathrm{C}_{\text {sample }}^{\mathrm{Rb}}$ is the concentration of $\mathrm{Rb}$ in the sample being studied, $\mathrm{C}_{\mathrm{Gr}}^{\mathrm{Rb}}$ is the concentration of $\mathrm{Rb}$ in granite, $\mathrm{C}_{\mathrm{PM}}^{\mathrm{Rb}}$ is the concentration of $\mathrm{Rb}$ in parent magma and $\mathrm{X}$ is the degree of contamination. Degree of granitic contamination for $\mathrm{Rb}$ has been estimated to range between zero and $83 \%$ for the mafic rocks (of Group 1) and $2-22 \%$ for the ultramafic rocks (of Group 2). Likewise, degree of granitic contamination for $\mathrm{Zr}$ has been estimated to range between zero and $63 \%$ for the mafic rocks (of Group 1) and 12-42\% for the ultramafic rocks of the present study. 


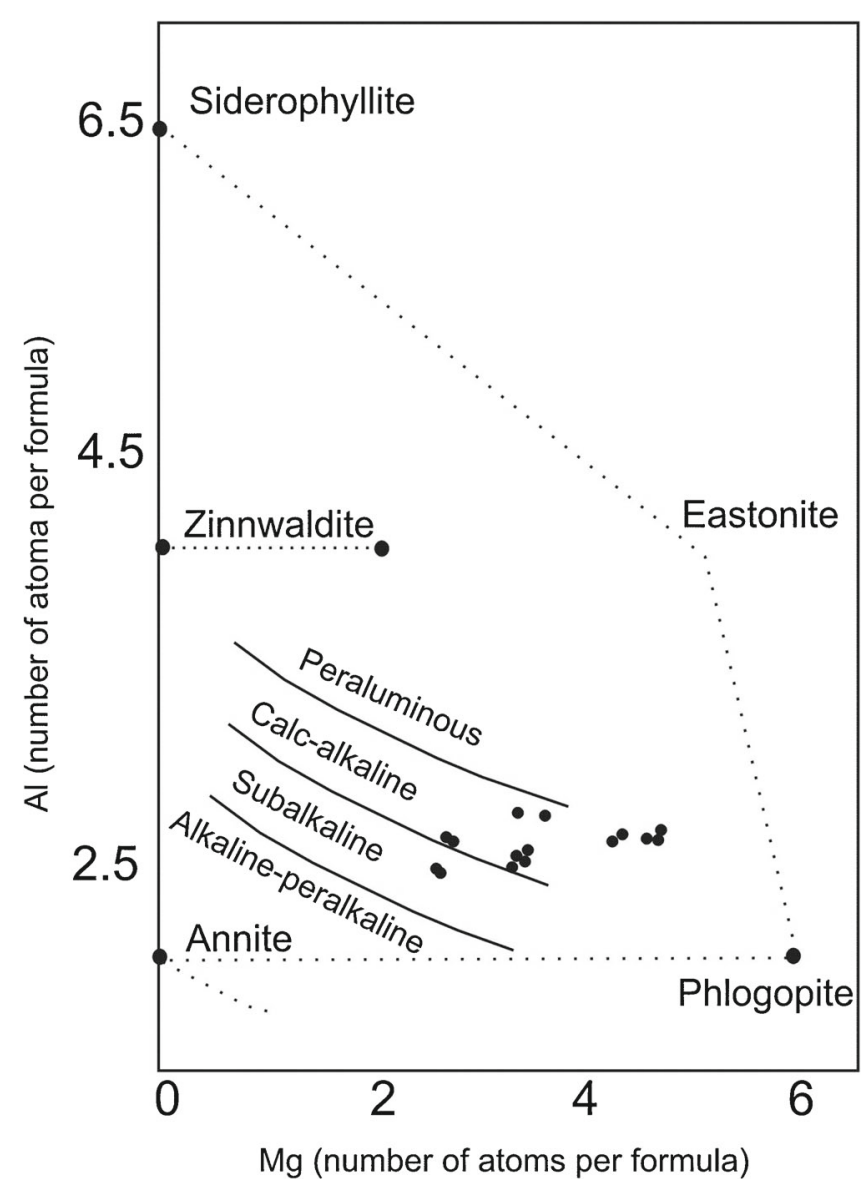

Figure 14. $\mathrm{Mg}-\mathrm{Al}$ variation diagram for the phlogopites of the present study (after Nachit et al. 1985 in Stussi and Cunney 1996). Note that majority of the phlogopites are plotted in the calc-alkaline field.

\subsection{Possible palaeotectonic settings}

Each specific tectonic setting is typified by the geochemical characteristics of constituent minerals of the intrusive rocks which can be used to recognize unknown tectonic setting of the old magmatic province. In the present research, phlogopite and clinopyroxene compositions are used to gather an idea about the paleotectonic setting in which mafic and ultramafic rocks were evolved.

Phlogopites, as stated earlier from North Puruliya Shear Zone intrusives are characterized by variable $\mathrm{Mg}$-number $\left(=\mathrm{Mg} /\left(\mathrm{Mg}+\mathrm{Fe}^{2+}\right)\right.$ ranging from 0.51 to 0.86 , and show mostly calc-alkaline nature when plotted in $\mathrm{Al}$ vs. $\mathrm{Mg}$ diagram after Nachit et al. (1985) (figure 14).

$\mathrm{Ti}-\mathrm{Al}$ plot of clinopyroxenes (figure 15, after Leterrier et al. 1982) show their concentration in the well-defined fields for Island arc tholeiites.

Characteristic features of mafic-ultramafic rocks of the present study are compared with other mafic-ultramafic complexes worldwide, e.g., ophiolite suite, layered mafic complex of Bushveld, South Africa, layered and deformed complexes of

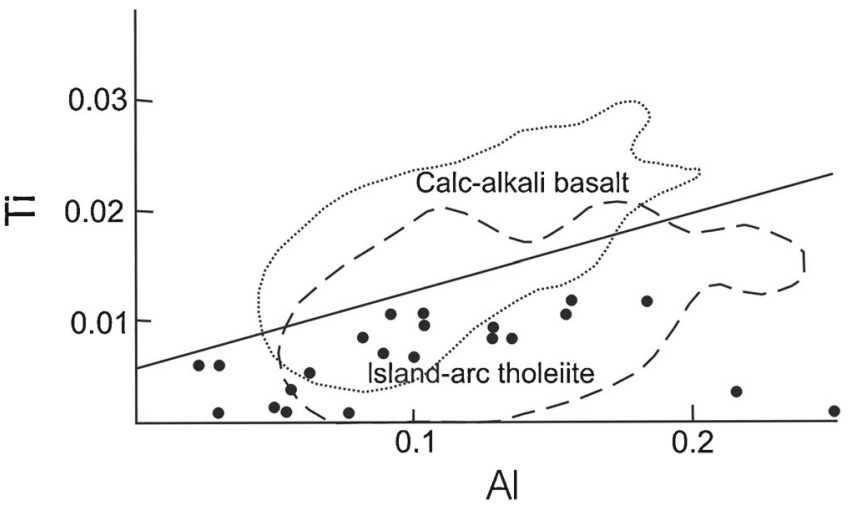

Figure 15. Ti-Al plots of clinopyroxene of mafic ultramafic rocks occurring along North Puruliya Shear Zone after Leterrier et al. (1982). Black filled circles represent clinopyroxene composition of present study falling in the field of 'island arc tholeiite'.

high-grade terrain of south India, mafic-ultramafic complex of Alaska (table 7).

\subsection{Status of mafic ultramafic rock in $C G C$}

Unmetamorphosed and undeformed ultramafic and mafic rocks occurring along a linear belt nearly parallel to North Puruliya Shear Zone is not found in other areas of CGC. Mahadevan (1992) reported schistose ultrabasic rock composed of chlorite + talc + actinolite from Puncha, Bispuria and Mahara areas which are metamorphosed and foliated. He also reported ultramafic rocks of unaltered nature from Bagaliya and Gaurangdih, far south from the present area of study. Mukherjee and Ghosh (1999) reported unmetamorphosed ultramafics from Damodar graben in parts of Bihar, far north from the present area of study. Thus, the present occurrence is unique and needs critical attention. Ultramafic-mafic rocks of the present study matches well with rocks of Alaskan type ultramafic-mafic complex in terms of their shape, major rock type, texture and mineralogy. More evolved and differentiated members of the maficultramafic rocks of the present study are composed of hornblende, plagioclase biotite and magnetite (together with accessory sphene, apatite and ilmenite). Irga and Palanja intrusives (figures 2 and 3) are concentrically zoned with ultramafic rocks at the core. Cumulus texture (figure 10) defined by early formed mafic minerals like olivine, orthoand clino-pyroxenes suggest fractional crystallization and accumulation. The common occurrence of hornblende and phlogopite in olivine websterite, lherzolite, gabbro, norite and dolerite indicate hydrous nature of magma characteristic of arcenvironment (Wilson 1989). Occurrence of large poikilic phlogopite (figure 8) which encloses early formed minerals like olivine, orthopyroxene, 


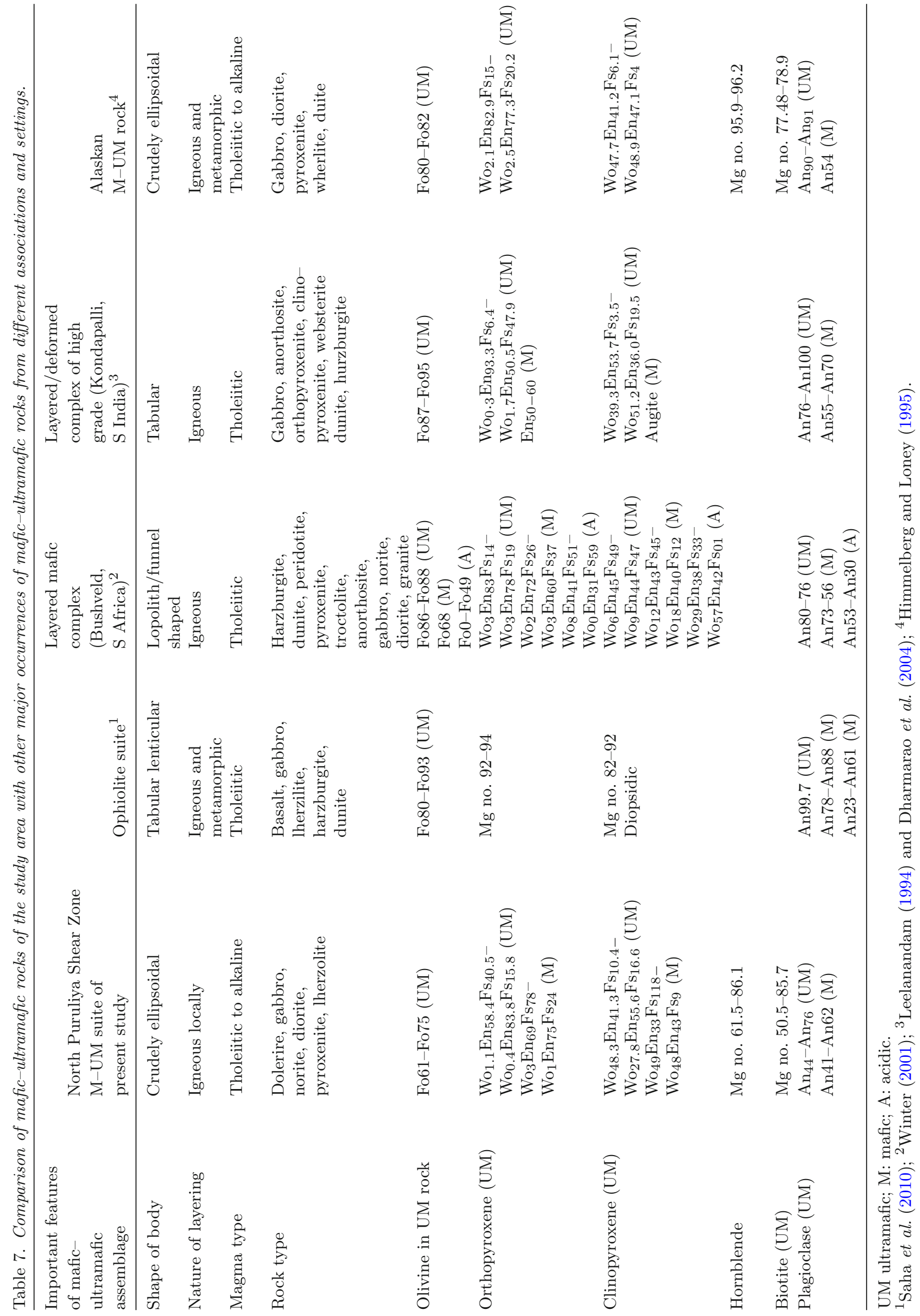


plagioclase possibly reflects reaction of cumulate minerals with aqueous fluid phase during late stage of crystallization as suggested by Costa et al. (2002). AFM variation diagram (figure 12) suggest tholeiitic to calc-alkaline nature of the mafic-ultramafic rocks. Chemical characteristics of phlogopite (figure 14) indicate its calc-alkaline nature and chemical composition of clinopyroxenes (figure 15) show affinity towards island arc environment.

\section{Conclusion}

Mafic and ultramafic intrusives occur along an east-west trending linear belt paralleling the North Puruliya Shear Zone. Individual exposure is crudely elliptical. Some of the intrusives show concentric lithological zoning, e.g., Irga, Palanja intrusive with lherzolite at the core followed by olivine websterite towards margin and ending with gabbro-norite. Rocks are characterized by cumulus and hypidiomorphic granular texture. Intrusives show both tholeiitic and calc-alkaline nature. Ultramafic cumulates are enriched in LILE and LREE and depleted in HREE. Negative Eu anomaly is characteristic in most of the rocks. From the mineralogical and geochemical studies, it may be postulated that mafic and ultramafic rocks are genetically linked and ultramafics are the lower cumulates and the mafic rocks are formed from more evolved magma of the same parental magma from which ultramafic rocks are formed.

\section{Acknowledgements}

Authors acknowledge the financial support received from DST, New Delhi, under the research grant (ref. no. SR/WOS/ES-27/2011). They also acknowledge the Head, Department of Geology, Presidency University, Kolkata, for infrastructural and analytical facilties, Wadia Institute of Himalayan Geology, Dehradun and NGRI, Hyderabad, for major and trace element analysis, Geological Survey of India, Kolkata, for EPMA study, Dr Sujit Bhadury, Saheli De and Jashodhara Chowdhury for XRF analysis at the Department of Geology, Presidency University, Trisha Lala and Achinta Mahato for field and laboratory works.

\section{References}

Baidya T K 1987 A new approach to the geologic history and mineral prospecting in Puruliya district, West Bengal; J. Mines Metals Fuels 32(12) 570-574.
Baidya T K and Chakravarty P S 1988 Mineralisation in the Belamu-Jaipur sector of northwestern Purulia district, West Bengal; In: Precambrian of the eastern Indian Shield (ed.) Mukhopadhyay D, Geol. Soc. India Memoir 8 147-165.

Baidya T K, Maity N and Biswas P 1989 Tectonic phases and crustal evolution in a part of the eastern Chhotanagpur Gneissic Complex; J. Geol. Soc. India 34(3) 318-324.

Beard J S 1986 Characteristic mineralogy of arc-related cumulate gabbros: Implications for the tectonic setting of gabbroic plutons and for andesite genesis; Geology 14 848-851.

Beccaluva L, Bianchini G, Bonadiman C, Siena F and Vaccaro C 2004 Coexisting anorogenic and subductionrelated metasomatism in mantle xenoliths from the Betic Cordillera (southern Spain); Lithos 75 67-87.

Bektas O, Eyoboglu Y, Sen C and Rojay B 2007 Reverlely zoned Alaskan-type mafic-ultramafic cumulates in the eastern pontide magmatic arc, NE Turkey; Geophys. Res. Abstr. 9 01036p.

Biggazzi G A, Del Moro F, Innocenti K, Kyriakopoulos P, Manetti P, Papadopoulos P, Norilliri A and Magganas 1989 The magmatic intrusive complex of Petrota, West Thrace: Age and geodynamic significance; Geol. Rhodopica 1 290-297.

Bonev N and Stampfli G 2005 Compositional diversity of the Evros ophiolite, Thrace, northeastern Greece: Field occurrences, preliminary petrologic and geochemical data on plutonic sequence and tectonic implications; Proc. Ann. Conf. Bulgarian Geol. Soc., pp. 28-31.

Bonev N and Stampfli G 2008 Petrology, geochemistry and geodynamic implications of Jurassic island arc magmatism as revealed by mafic volcanic rocks in the Mesozoic low-grade sequence, eastern Rhodope, Bulgaria; Lithos $100210-233$.

Boudreau A E 1999 Fluid fluxing of cumulates: The J-M Reef and associated rocks of the Stillwater Complex, Montana; J. Petrol. 40 755-772.

Chatterjee N, Crowley J L and Ghose N C 2008 Geochronology of the $1.55 \mathrm{Ga}$ Bengal anorthosite and Grenvillian metamorphism in the Chotanagpur gneissic complex, eastern India; Precamb. Res. 161(3-4) 303-316.

Costa F, Dungan M A and Singer B S 2002 Hornblende- and phlogopite-bearing gabbroic xenoliths from Volcán San Pedro ( $\left.36^{\circ} \mathrm{S}\right)$, Chilean Andes: Evidence for melt and fluid migration and reactions in subduction-related plutons; J. Petrol. 43(2) 219-241.

Das D K 1977 A review on sulphide zone around Belamu hill, Puruliya, West Bengal; J. Mines Metals Fuels, Puruliya Seminar, Special Number, 75-77.

Das A and Bhattacharyya C 2007 Alkaline granitoids from Northern Shear Zone of Puruliya District, West Bengal; J. Geol. Soc. India 69 1208-1214.

Dharmarao C V, Vijaya Kumar T and Bhaskar Rao Y J 2004 The Pangidi anorthosite complex, Eastern Ghats granulite belt India: Mesoproterozoic Sm-Nd isochron age and evidence for significant crustal contamination; Curr. Sci. $87(11)$.

Ghosh N C 1983 Geology, tectonics and evolution of the Chhotanagpur granite-gneiss complex, eastern India; In: Recent Researches in Geology (ed.) Sinha Roy S, Hindustan Publishing Company, India 10 211-247.

Ghosh N C 1992 Chhotanagpur gneiss-granulite complex, eastern India: Present status and future prospect; J. Geol. India 64(1) 100-121.

Himmelberg G R and Loney R A 1995 Petrogenesis of gabbronorite at Yakobi and northwest Chicago islands, Alaska; Geol. Soc. Am. Bull. 98 265-279. 
Irvine T N 1980 Magmatic infiltration metasomatism, double diffusive fractional crystallisation, and adcumulous growth in the Muscox intrusion and other layered intrusions; In: Physics of magmatic processes (ed.) Hargraves R B (Prinston, NJ: Prinston University Press), pp. 325-383.

Irvine T N and Baragar W R A 1971 A guide to chemical classification of the common volcanic rocks; Canadian J. Earth Sci. 8 523-548.

Janet M Hergt and Donald R Sims Jr 1994 Data report: Assessment of the precision of LEG 135 shipboard XRF analyses and the contamination introduced by crushing in tungsten carbide; In: Proceedings of the Ocean Drilling Programme; Scientific Results 135 925-929.

Kumar A and Ahmad T 2007 Geochemistry of the mafic dykes in parts of Chotanagpur gneissic complex: Petrogenetic and tectonic implications; Geochem. J. 41 173-186.

Leelanandam C 1994 The Kondapalli layered complex, Andhra Pradesh, India: Geology, mineralogy and chemistry; Goldschmidt Conference Edinburgh, pp. 517-518.

Leterrier J, Mnury R C, Thonon P, Girard D and Marchal M 1982 Clinopyroxene composition as a method of identification of the magmatic affinities of the paleo-volcanic series; Earth Planet. Sci. Lett. 59 139-154.

Mahadevan T M 1992 Geological evolution of the Chhotanagpur gneissic complex in part of Purulia District; Ind. J. Geol. 64(1) 1-22.

Maji A K, Goon S, Bhattacharyya A, Misra B, Mahato S and Bernhardt H J 2008 Proterozoic polyphase metamorphism in Chhotanagpur gneissic complex (India) and implication for trans-continental Gondwanaland correlation; Precamb. Res. 162 385-402.

Maji A K, Patra A and Ghosh P 2010 An overview on geochemistry of Proterozoic massif-type anorthosites and associated rocks; Earth Syst. Sci. 119(6) 861-878.

Mandal A, Goswami B, Mukherjee S, Das S, Bhattacharyya I and Bhattacharyya C 2007 Mantle metasomatism of ultramafic intrusives in Chhotanagpur granite gneiss complex, Puruliya District, West Bengal, eastern India: Evidence from trace element and REE geochemistry; In: Igneous Petrology: 21st Century Perspective (eds) Ray J S and Bhattacharyya C, Allied Publishers Pvt. Ltd., pp. $122-142$.

Mandal A and Ray A 2009 Petrology of mafic-ultramafic rocks along North Puruliya Shear Zone, West Bengal; J. Geol. Soc. India 74 108-118.

McBirney A R 1995 Mechanisms of differentiation in the Skaergaard intrusion; J. Geol. Soc. London 152 421-435.

Misra S 2006 Precambrian chronostratigraphic growth of Singhbhum-Orissa craton, eastern Indian shield: An alternative model; J. Geol. Soc. India 67 356-378.

Mukherjee D and Ghosh N C 1999 Damodar graben: A centre of contrasting magmatism in the eastern Indian shield margin; In: Basement Tectonics (ed.) Sinha A K, 13 179-202.
Nachit H, Rajafimahefa N, Stussi J M and Karoon J P 1985 Composition chimique des biotites et typologie magmatique des granitoids; Comptes rendu de I, Academic des Science, Paris, 301 813-818.

Rama Rao B, Radhakrishna B P and Ramakrishnan M 1990 Archaean greenstone belts of south India; Geol. Soc. India, 497p.

Ray Barman T and Bisui P K 1994 Dating of Chhotanagpur gneissic complex of eastern Indian shield; Rec. Geol. Soc. India 127(2) 25-27.

Rollinson H R 1993 Using geochemical data: Evaluation, presentation, interpretation; Longmans Harlow, New York, $10,158 \mathrm{p}$.

Saha A et al. 2010 Complete preservation of ophiolite suite from south Andaman, India: A mineral-chemical perspective; J. Earth Syst. Sci. 119(3) 365-381.

Sengupta D K 1958 On a relict metadolerite sill in the granitic complex in the vicinity of Jhalida, Purulia district; Proceedings 45th Indian Science Congress, Abstract, 236p.

Sengupta D K and Sarkar S N 1968 Structure of the granitic rock and associated metamorphites of the area around Muri-Silli-Jhalida, Ranchi and Purulia districts, India; Trans. Geol. Metal. Inst. India 65(2) $1-18$.

Singh K N 1959 A preliminary note on the petrology of the area northwest of Jhalida (district Purulia, West Bengal); Sci. Cult. 25(2) 154p.

Srivastava R K, Sinha A K and Kumar S 2012 Geochemical characteristics of Mesoproterozoic metabasitedykes from the Chhotanagpur gneissic terrain, eastern India: Implications for their emplacement in a plate margin tectonic environment; Earth Syst. Sci. 121(2) 509-523.

Streckeisen A L 1973 Classification and nomenclature recommended by the I.U.G.S. subcommission on the systamatics of igneous rocks; Geotimes 18(10) $26-30$.

Stussi J M and Cuney 1996 Nature of biotites from alkaline, calc-alkaline and peraluminous magmas by Abdel-Fattah M Abdel-Rahman: A comment; J. Petrol. 35(5) 10251029 .

Taylor S R and McLennan S M 1985 The Continental Crust: Its composition and evolution; an examination of the geochemical record preserved in sedimentary rocks; Blackwell, Oxford. 312p.

Tseng T L, Chen W P and Nowack R L 2009 Northward thinning of Tibetan crust revealed by virtual seismic profiles; Geophys. Res. Lett. 36 L24304, doi: 10.1029/2009GL040457.

Wilson M 1989 Igneous Petrogenesis: A Global Tectonic Approach; London (Unwin Hyman), 466p.

Winter J D 2001 An introduction to igneous and metamorphic petrology, Prentice Halll, 224p. 